\title{
58. CHRONOLOGY AND BIOSTRATIGRAPHY OF NORTHEAST ATLANTIC SEDIMENTS, DSDP LEG 48
}

\author{
Ernest A. Hailwood, ${ }^{1}$ Wayne Bock, ${ }^{2}$ Lucy Costa, ${ }^{3}$ Pierre A. Dupeuble, ${ }^{5}$ Carla Müller, ${ }^{4}$ and Detmar Schnitker ${ }^{6}$
}

\section{INTRODUCTION AND GENERAL OBJECTIVES}

In this chapter the principal results of each of the stratigraphic investigations on DSDP Leg 48 material are brought together, and an attempt is made to produce a general correlation among the biostratigraphic zonation schemes based on different fossil groups. An important objective is to place the biostratigraphic zonations within the framework of a numerical time scale by means of paleomagnetic reversal chronology.

On DSDP Leg 48, six holes $(399,400,400$ A; 401; 402, $402 \mathrm{~A}$ ) were drilled at three sites in the northeast Bay of Biscay and four holes were drilled at four sites near the southwest extremity of the Rockall Plateau (403 to 406). Locations of these sites are shown elsewhere in this volume.

The sequences encountered in both areas are distinguished by a number of important hiatuses (Figure 1), but, by combining sections from all sites, a fairly complete composite sequence is obtained which extends from the Upper Cretaceous to the Quaternary. Lower Cretaceous sections were recovered at Holes 400A, 401, and 402A.

In Part I of this paper the quality of the paleontological material obtained on Leg 48 is assessed, and the relative merits of the different major fossil groups (foraminifers, nannofossils, and dinoflagellate cysts), as high latitude stratigraphic indicators, are examined. Justification of the choice of biostratigraphic zonal boundaries in this study is made, and some paleoceanographic implications are briefly considered.

In Part II of this paper the detailed late Neogene magnetic polarity stratigraphy derived for the sediments cored in Hole $400 \mathrm{~A}$ is correlated with the well-established magnetic polarity time scale for the past $10 \mathrm{~m} . \mathrm{y}$. The resulting age-versus-depth calibration for the site is then used to assign a numerical age to each of the principal late Neogene zonal boundaries therein identified, allowing the North Atlantic late Neogene biostratigraphic zonation scheme to be placed within an "absolute" time framework. U.K.

'Department of Oceanography, University of Southampton, SO9 5NH,

${ }^{2}$ Rosenstiel School of Marine and Atmospheric Sciences, Miami, Florida

${ }^{3}$ Department of Geology, University of Sheffield, Mappin Street, Sheffield, S1 3JD, U.K.

${ }^{4}$ BEICIP, 366 Avenue Napoléon Bonaparte, B.P. 13 - 92502 Rueil-Malmaison, France

${ }^{5}$ Laboratoire de Géologie, Faculté des Sciences, Université de Rouen, 76130-Mont-Saint-Aignan, France

${ }^{6}$ Department of Oceanography, University of Maine at Orono, Walpole, Maine
In Part III of this paper the combined paleomagnetic-biostratigraphic studies of early Paleogene sediments recovered at Sites 403 to 405 are combined with the early Paleogene magnetic stratigraphy from the Italian Gubbio section (Premoli Silva et al., 1974), and the age of sediments overlying identifiable marine magnetic anomalies at other DSDP sites. On the basis of this synthesis, significant amendments are proposed to currently accepted versions of the Paleogene and earliest Neogene magnetic polarity time scale, and a revised magnetic polarity time scale is produced for the whole of the Cenozoic era. The correlation of the magnetic polarity chronology recorded in Leg 48 sediment cores with the pattern of magnetic anomalies identified in the oceanic lithosphere allows the dating of certain important tectonic and oceanographic events, such as the time of opening of the northeast Atlantic between Greenland and Rockall.

In Part IV the Early Cretaceous magnetic polarity determinations from Holes $400 \mathrm{~A}$ and $402 \mathrm{~A}$ are evaluated, and biostratigraphic studies on these sediments are used to place constraints on the possible ages of certain short reversed polarity events within the long Cretaceous interval of dominantly normal polarity.

Finally, a summary of the proposed correlations between northeast Atlantic foraminifers, nannoplankton, and dinocyst zones is presented, and similarities and differences between the positions of zonal boundaries in Cenozoic sediments from the northeast Atlantic and the "standard" low-latitude zonation schemes are discussed. The correlation of the principal late Neogene foraminiferal and nannoplankton zones with the magnetic reversal time scale allows, within the framework of an "absolute" time scale, comparisons to be made between the northeast Atlantic and Mediterranean biostratigraphic records.

\section{PART I: BIOSTRATIGRAPHY AND BIOGEOGRAPHY}

Influence of Latitude Upon Biostratigraphy

The standard biostratigraphic zonation schemes for marine planktonic organisms are based mainly upon the rich and highly differentiated fossil biota of the world's tropical areas, and the strong decline in species' richness of the biosphere from tropical to polar climates is of overwhelming significance to the biostratigrapher. The incidence of initiation and extinction of species is far greater at low latitudes than among the few species that exist at high latitudes. In addition, climatic change results in latitudinal shifts in range, especially of the middle and high latitude species, so that the faunal and floral record from these latitudes records 


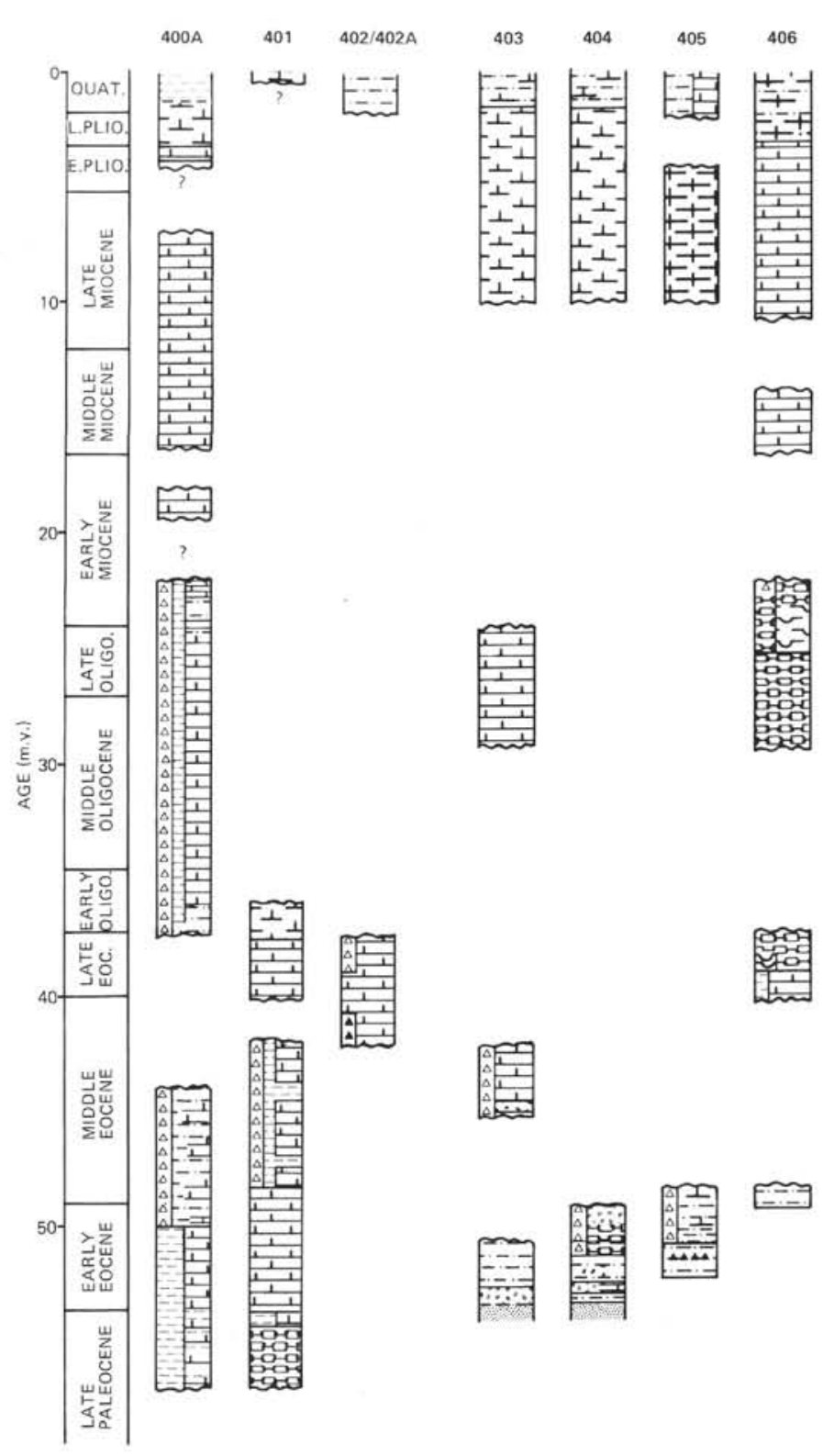

Figure 1. Lithological summary for DSDP Leg 48 sites.

chronological as well as climatic information. During the late Neogene, climatic oscillations became pronounced and are responsible for a considerable part of the faunal and floral variations encountered in the records.

The first high latitude excursion of Glomar Challenger, DSDP Leg 12, proved that biostratigraphic zonation schemes established on tropical faunal and floral successions could not be applied readily to the stratigraphy of the North Atlantic (Berggren, 1972a; Perch-Nielsen, 1972; Bukry, 1972; and Benson, 1972). These authors found that many of the age-diagnostic species, and sometimes whole groups of species, were missing, and the resolving power of the biostratigraphy was sharply reduced when compared with tropical material.

Although Poore and Berggren (1974) later developed a detailed calcareous plankton zonation for the Pliocene of the Labrador Sea, the experience of DSDP Leg 38 in the

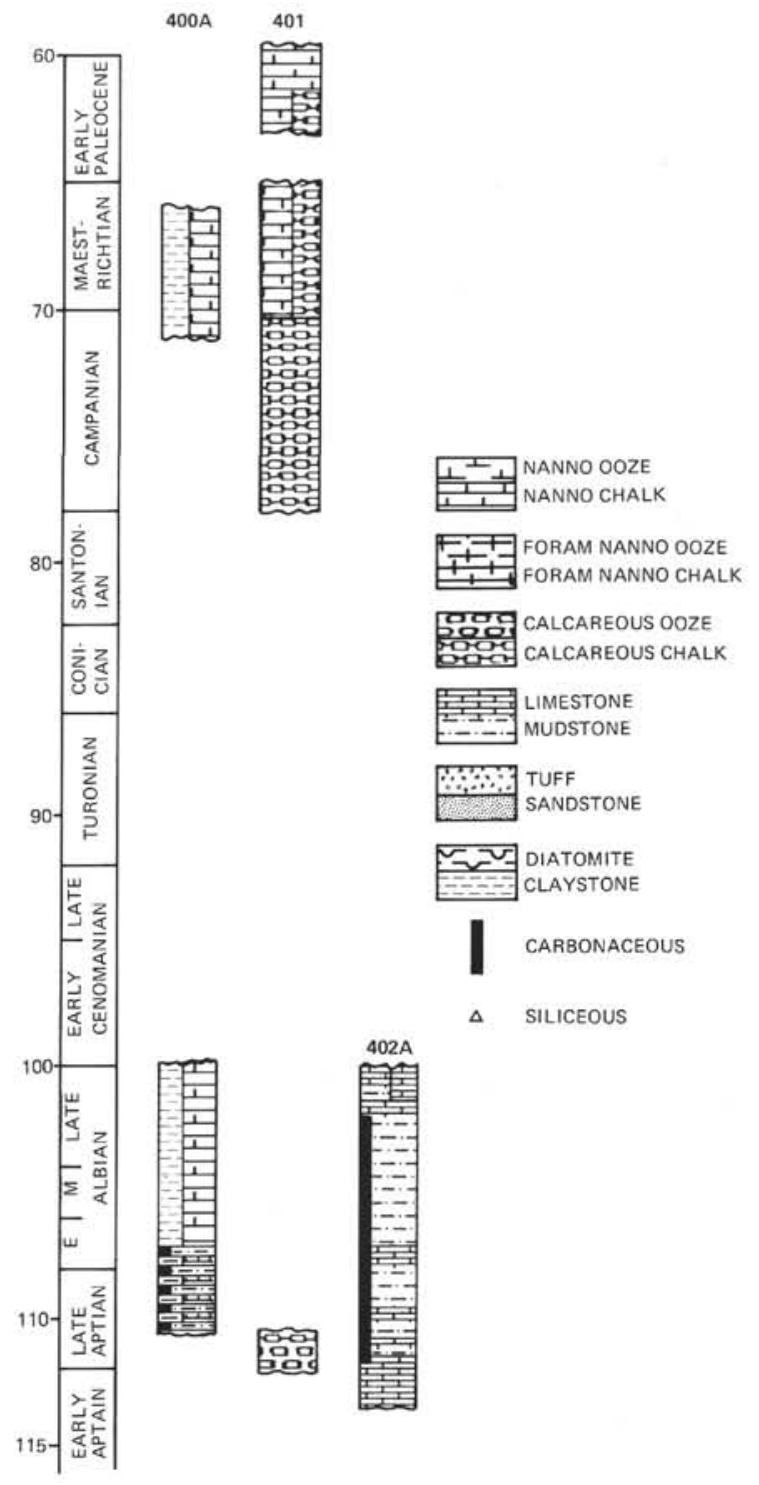

Norwegian-Greenland Sea demonstrated that at those latitudes planktonic foraminifers ceased to be useful and calcareous nannoplankton were only of limited value. However, siliceous planktonic organisms (silicoflagellates, diatoms, and radiolarians) provided a somewhat more detailed biostratigraphy (Müller, 1976; Martini and Müller, 1976; Schrader and Fenner, 1976; Bjørklund, 1976) although the diatom and radiolarians schemes were local and a dinocyst zonation scheme proposed by Manum (1976) had limited value for correlation.

Biostratigraphic observations made on other high latitude DSDP legs (Legs 18, 19, North Pacific; Legs 28, 29, 35 and 36, Antarctic), proved that, in those regions, calcareous plankton suffered from low species diversity and, often, extensive carbonate dissolution, whereas siliceous plankton generally offered a better biostratigraphy because of higher species' diversity and better preservation. 


\section{Quality of the Leg 48 Paleontological Material}

The quality of microfossils and, thus, of the paleontological record from the Leg 48 sites, varies sharply with location and geological age. Greatest damage was caused by carbonate dissolution, which in general was most severe on forms of late Eocene to late middle Miocene age. Calcareous microfossils suffered more at the deeper sites (e.g., the Paleogene sequence in Hole 400A) than at the shallower sites (e.g., Sites 401 and 402). Planktonic foraminifers were more susceptible to dissolution than were calcareous nannoplankton.

The situation is further complicated by the occurrence of several important hiatuses (Figure 1). The most complete section recovered was from Hole 400A, but the strong dissolution of planktonic foraminifers, particularly in the Paleogene sections, severely limits establishing correlations between Paleogene foraminiferal and nannoplankton zones at this site.

Zonal correlations are more successful for the Paleogene sediments recovered at Site 401 and Hole 402A, drilled in shallower water. These sediments yielded well-preserved and highly diversified planktonic foraminiferal assemblages, with the exception of the middle Eocene and upper part of the middle Miocene sections, in which dissolution of calcareous micro- and nannofossils is strong.

Precise determination of foraminifer and nannoplankton zones for the Neogene (Hole 400A and Site 406) was not always possible due to absence or scarcity of index fossils. This may be attributed to decrease of water temperatures at these sites in latest Eocene times.

Abundant calcareous nannofossils and dinoflagellates, mainly in the Paleogene of the Rockall Sites (403-406, Costa and Downie, this volume), provides opportunity to correlate zonal schemes for these two fossil groups. This correlation is summarized in Figure 2, and discussed in detail by Costa and Müller (in press).

The sampling densities employed for the various fossil groups varied greatly, roughly in proportion to the ease with which samples could be processed and determinations made. Five or more samples per core were examined for calcareous nannoplankton, and one to two samples per core for planktonic foraminifers. On the average, one sample per core was investigated for dinocysts, but in zones of special interest up to five samples per core were processed and as few as one sample per five or six cores in zones of poor dinocyst preservation and/or abundance.

\section{Definition of Zonal Boundaries for the Cenozoic}

As with other North Atlantic biostratigraphic studies, we have attempted to base our correlations upon the "standard" zonation schemes and definitions of Blow (1969) and Berggren (1971) for planktonic foraminifers, and of Martini (1971) for the calcareous nannoplankton. Wherever possible we based our zone boundaries upon the nominate species of the original zone definition but, in those cases where the nominate species were absent, different species whose ranges are reasonably well known from areas where they occur together with the nominate species were utilized. These "non-standard" zonal boundaries are summarized below.
Nannoplankton: The standard nannoplankton zonal definitions can in general be used without difficulties for the Paleogene sequences at Biscay and Rockall, but the zones and their boundaries are commonly difficult to determine in Neogene sections.

The boundary between the middle Eocene Zones NP 15 and NP 16, defined by the extinction of Rhabdosphaera gladius, could not always be recognized at sites where middle Eocene sediments were recovered. This species appears to be restricted to deposits of a shallow water, near-shore environment; it is not found in open ocean deposits.

The absence of Sphenolithus pseudoradians prevents the determination of the boundary between the late Eocene Zones NP 19 and NP 20.

It is sometimes very difficult to recognize the Eocene/Oligocene boundary because of the scarcity or absence of discoasters. The extinction of Cribrocentrum reticulatum appears to be a useful biostratigraphic event for the determination of this boundary.

Nannoplankton Zones NP 24 and NP 25 of the middle and late Oligocene had to be combined because of the sporadic occurrence or lack of diagnostic sphenoliths.

The Oligocene/Miocene boundary which is normally defined by the extinction of Helicosphaera recta, had to be determined in this study on the extinction of Dictyococcites dictyodus and Zygrhablithus bijugatus.

Precise determination of the earliest Miocene nannoplankton Zones NN 1 and NN 2, as well as those of the late middle Miocene (NN 8 to lower NN 10), is difficult due to the absence of index fossils.

As discussed later, only combined nannoplankton Zones NN 12 and NN 13, NN 14 and NN 15, and NN 17 and NN 18 can be used for a subdivision of the Pliocene.

The extinction of Discoaster brouweri, which elsewhere marks the Pliocene/Pleistocene boundary, occurs here within Zone NN 16. However, the extinction of Cyclococcolithus macintyrei appears to be a useful alternative for the determination of this boundary (Müller, 1977; Bizon and Müller, 1977, 1978). A more detailed discussion of Leg 48 calcareous nannoplankton biostratigraphy is presented by Müller (this volume).

Planktonic foraminifers: Only a few of the nominate species of the Blow (1969) and Berggren (1971) zone definitions were found in the material used for this study. Zonal age assignments most often were based upon the total foraminiferal contents of samples, the composition of which varied markedly between coeval samples from different sites and, in particular, between the two regions, Biscay Bay and Rockall. Thus, faunal zones that are recognizable at one site may not be at another.

The late Paleocene Zone P.4 could not be clearly delineated from Zone P.5. Globorotalia pseudomenardii, the nominate species for Zone P.4, disappears together with G. pusilla pusilla before the first appearance of Globigerina nitida.

The boundary between the early Eocene Zones P.6b and P.7 was placed at the last occurrence of Globigerina velascoensis. Globorotalia aragonensis, whose first occurrence defines this boundary, is absent. Early Eocene sediments at all Rockall sites were characterized by a poor 
(a) NEOGENE

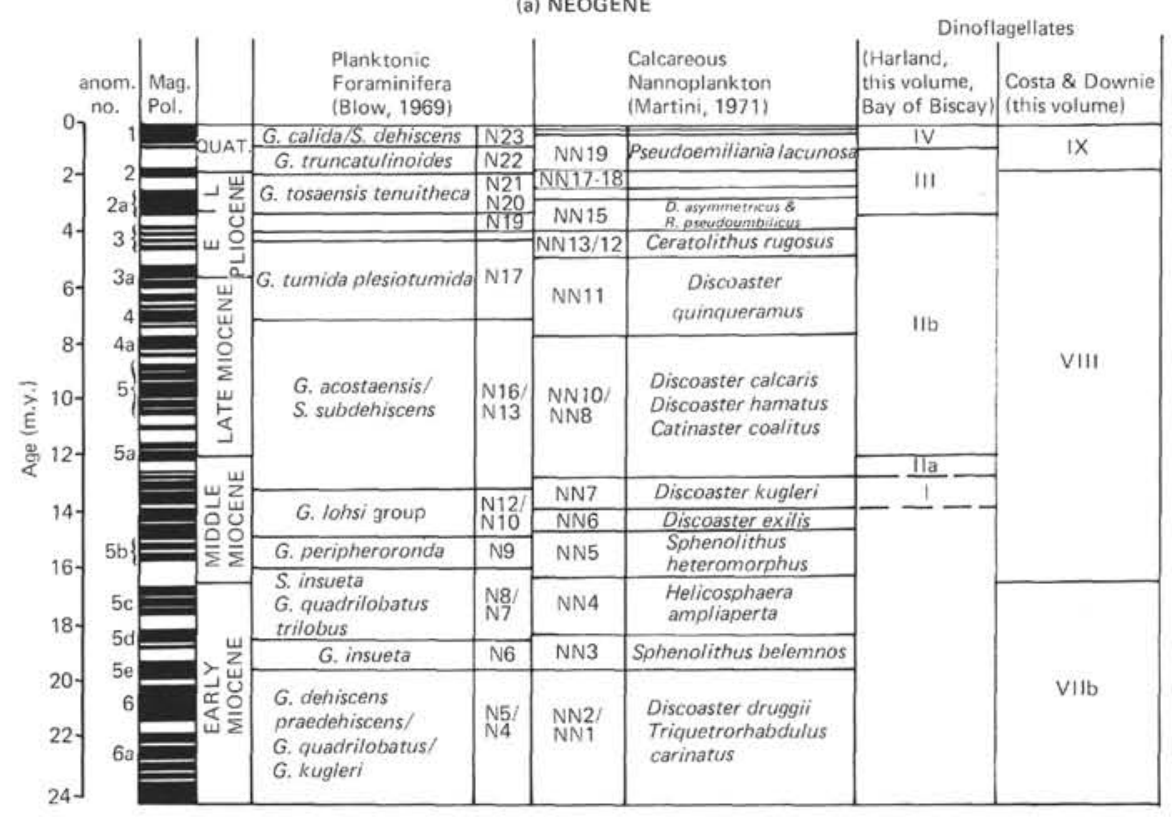

(b) PALEOGENE

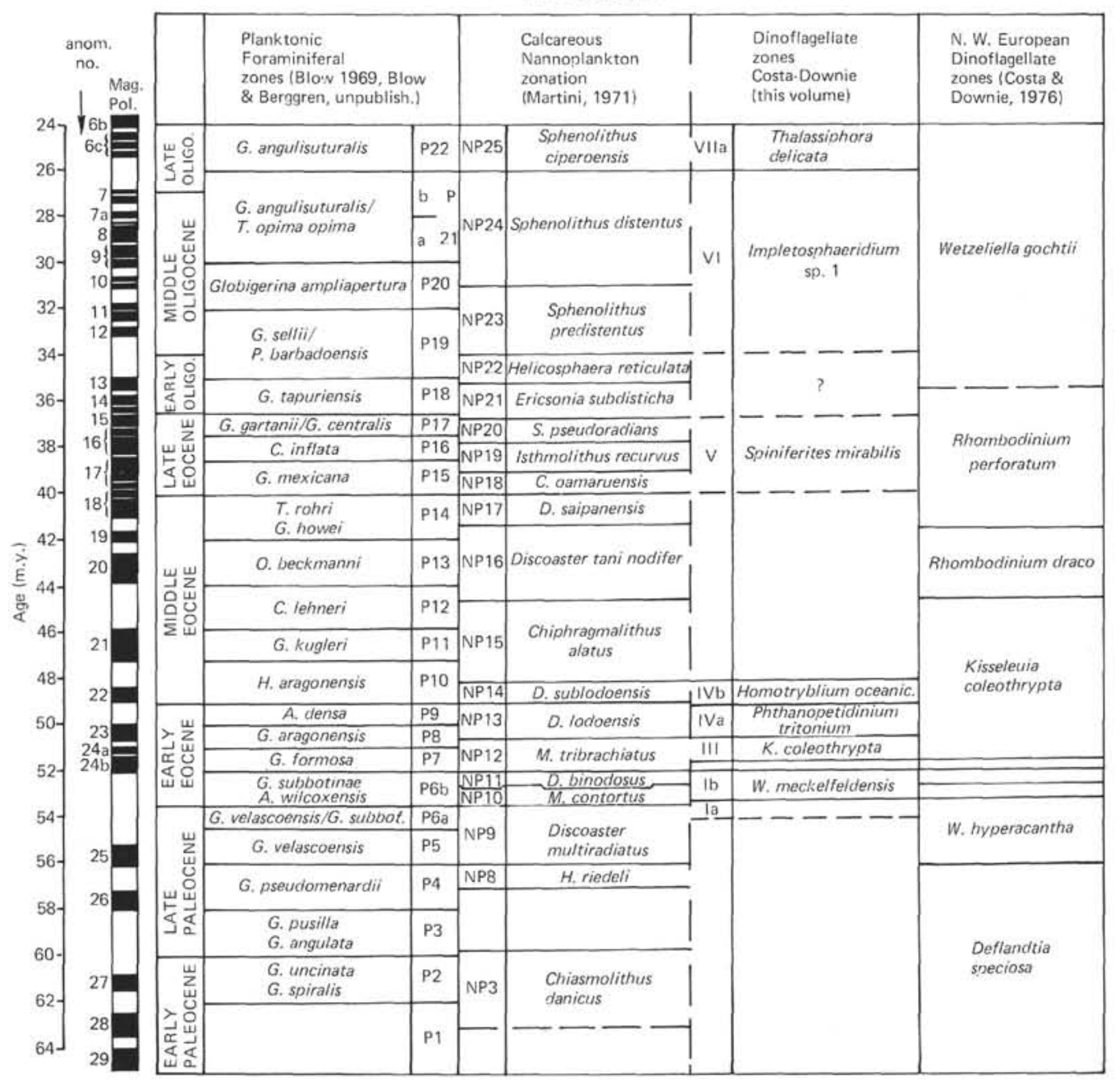

Figure 2. Proposed correlation between Neogene, Paleogene, and Cretaceous biostratigraphic scales for the Northeast Atlantic, and magnetic polarity time scale. 


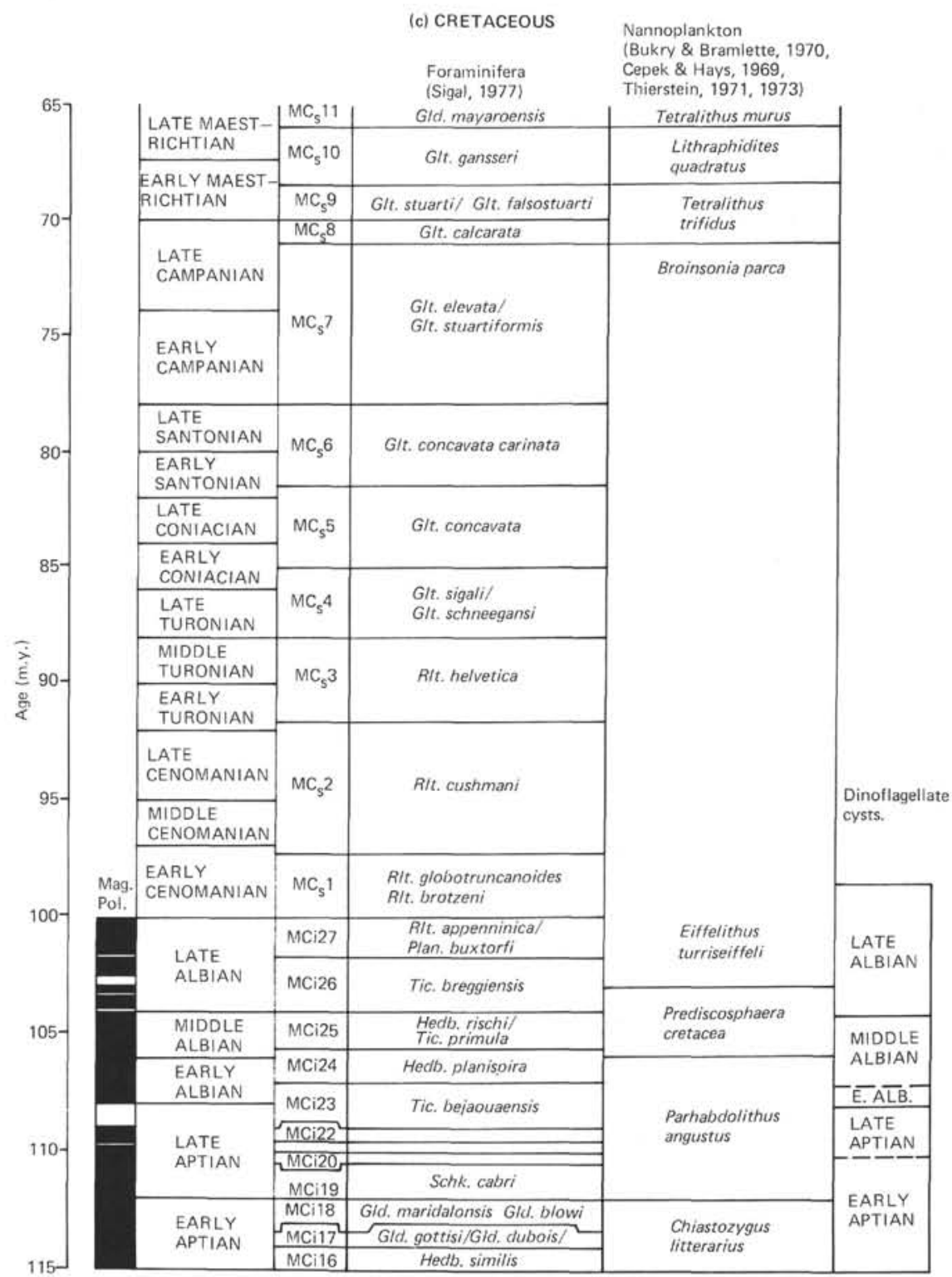

Figure 2. Continued. 
fauna of such long-ranging species groups as Globigerina primitiva and $G$. linaperta. Here, the first occurrence of Globorotalia bullbrooki was accepted as indication of the middle Eocene, the base of Zone P.10. Middle Eocene Zones P.10 to P.14 at the Rockall sites cannot be clearly defined because of sporadic occurrence of diagnostic species. At Biscay Bay, the base of the early Eocene Zone P.9, defined by the first occurrence of Globorotalia palmerae, is here placed at the first occurrence of $G$. caucasica and $G$. pentacamerata.

The extinction of $G$. caucasica and the first appearance of G. bullbrooki and Truncorotaloides rohri were used to recognize the early/middle Eocene boundary, the base of Zone P.10. The base of Zone P.11 was placed at the level of the first occurrence of Globorotalia lehneri; the base of Zone P.12 at the level of extinction of $G$. broedermanni; the base of Zone P.13 at the level of the last occurrence of $G$. pentacamerata and the first occurrence of Globorotaloides suteri; the base of Zone P.14 at the level of the last occurrence of Globigerinatheka kugleri and the first appearance of Globigerinita unicava; the top of Zone P.14, the middle to late Eocene boundary, at the level of extinction of the nominate species Truncorotaloides rohri.

The late Eocene foraminiferal zones at Rockall, like those of the middle Eocene, cannot be clearly differentiated. Foraminiferal associations characteristic of each of Zones P.15, P.16 and the lower portion of Zone P.17 are present, but species that would allow the recognition of the boundaries between these zones occur only sporadically. At Biscay Bay, the boundary between the late Eocene Zones P.15 and P.16 was characterized by the first occurrence of Globorotalia cocoaensis.

The Oligocene foraminiferal Zones P.19 and P.20 were differentiated by the extinction of Pseudohastigerina micra at the top of Zone P.19. The top of Zone P.20 was marked by the disappearance of Globorotalia increbescens, and the top of Zone P.21 by the last occurrence of the nominate species $G$. opima opima.

The Oligocene/Miocene boundary, i.e., the top of Zone P.22, is rather poorly marked by the first occurrence of Globigerinita incrusta and the extinction of Globigerina tripartita. Few of the early and middle Miocene zonal boundaries were recognizable and those only with low levels of confidence. The base of foraminiferal Zone N.6 is placed at the level of first occurrence of Globorotalia peripheroronda. Zones N.6, N.7, N.8, and N.9 could not be readily differentiated. The boundary between foraminiferal Zones N.9 and N.10 is here marked by the last occurrence of $G$. praescitula and the appearance of $G$. praemenardii. Foraminiferal Zones N.10 and N.11 had to be combined, their top being recognized by the last occurrence of $G$. peripheroronda .

The late Miocene foraminiferal Zones N.16 and N.17 were separated by the last appearance of Globoquadrina dehiscens at the top of Zone N.16. The top of the foraminiferal Zone N.17, the Miocene/Pliocene boundary was placed at the level of the last occurrence of Globorotalia continuosa and the appearance of $G$. margaritae. The base of foraminiferal Zone N.19 is recognized here by the appearance of $G$. puncticulata. The top of foraminiferal Zone N.19 appears to be marked by the last occurrence of $G$. conomiozea andacostaensis (?) and the appearance of $G$. crassaformis. The appearance of $G$. inflata marks the top of foraminiferal Zone N.20. G. tosaensis, the nominate species for foraminiferal Zone N.21, occurs too rarely to be of use as a reliable indicator.

The appearance of $G$. truncatulinoides marks the Pliocene/Pleistocene boundary, the limit between foraminiferal Zones N.21 and N.22-23.

Dinoflagellate cysts: Because standard dinoflagellate cyst zonation covering the whole of the Cenozoic is not yet available, a provisional scheme was established for the Rockall area, including nine partial-range biozones ranging from late Paleocene to Pleistocene. This scheme is mostly based on the distribution of species which have already proved stratigraphically useful in well established European and North American sequences. This allows a dating of the cores and a detailed correlation with classical on-shore sections.

\section{Paleogene}

From the late Paleocene to the middle Eocene the dinocyst assemblages from Rockall bear close resemblances to contemporaneous European assemblages. Of particular interest for the purpose of dating and correlation of the sections in Rockall, are the Paleogene beds of southeast England, the dinocyst succession of which has been studied in detail and is very similar to the succession in Sites 403 to 406. Thus, the following correlations have been established:

Zone Ia equates with the Woolwich Beds to basal London Clay of England, and is equivalent to the Apectodinium hyperacanthum Zone of northwest Europe (Costa and Downie, 1976).

Zone $\mathrm{Ib}$ equates with the lower to middle London Clay, and includes the Wetzeliella meckelfeldensis and Dracodinium similis Zones of northwest Europe (Costa and Downie, 1976).

Zone II correlates with the upper London Clay and equates with the Dracodinium varielongituda Zone of northwest Europe (Costa and Downie, 1976).

Zone III is equivalent to the uppermost London Clay of Kent and the lowermost Bracklesham Beds (Zones 1 and 2 of Eaton, 1971); it equates with the lower part of the Kisselevia coleothrypta Zone of northwest Europe (Costa and Downie, 1976).

Zone IVa correlates with Zone 3 of the Bracklesham Beds (Eaton, 1971).

Zone IVb equates with Eaton's Zone 4 of the Bracklesham Beds, and is middle Eocene (Lutetian).

Above Zone $\mathrm{IVb}$, there is a hiatus including the latest middle Eocene and the earliest late Eocene. The assemblages from Zones V, VI, and VII are rather different in composition from late Eocene and Oligocene assemblages in European sequences, and they also appear to differ from contemporaneous North American assemblages. There are, however, some stratigraphically critical species in common, which allow correlations although not in as much detail as for the zones older than Zone V. In general terms, Zone V appears to equate with the Upper Barton and Headon Beds of England; Zone VI is apparently equivalent to the late Rupelian/Chattian of north Germany; Zone VII 
seems to equate with the latest Oligocene (Chattian) to early Miocene of north Germany.

From the mid-upper Oligocene stratigraphic level onwards, there appears to be a close affinity between the dinocyst assemblages from Rockall and those from the Norwegian-Greenland Sea described by Manum (1976). This affinity is even closer onwards from the middle Miocene.

\section{Neogene}

Not enough is known about dinocyst assemblages from the European Miocene to establish any comparisons. The Miocene assemblages from Rockall are poorer and less diversified than contemporaneous assemblages from the Bay of Biscay (Harland, this volume); they also appear to be poorer than Miocene assemblages from offshore eastern Canada. The dating of Neogene zones rests considerably on correlation with calcareous micro- and nannofossil zones. However, the studied cores can also be dated by comparisons with dinocysts assemblages from the NorwegianGreenland Sea.

\section{Cretaceous Micropaleontology}

Cretaceous sediments were recovered from the Bay of Biscay at Holes 400A, 401, and 402A, and biostratigraphic ages have been derived from planktonic foraminifers, calcareous nannoplankton, and palynomorphs. The foraminiferal zones are based on the scheme proposed by Sigal (1977). The nannofossil zonation established by Thierstein $(1971,1973)$ has been used for the Early Cretaceous, and a combination of the zonation schemes of Čepek and Hay (1969) and Bukry and Bramlette (1970) for the Late Cretaceous.

In general, the age determinations from the different fossil groups are in good agreement. A significant exception is the lowermost sediments recovered from Hole 400A, which have been assigned to the late Aptian on the basis of calcareous micro- and nannofossils, whereas dinoflagellate cysts suggest an early Aptian age. Small discrepancies exist in the exact location of the Aptian/Albian boundary defined by the different fossil groups. A correlation between the biostratigraphic scales established for these different fossil groups in the Bay of Biscay is shown in Figure 2.

An important hiatus separates the Early Cretaceous sediments at Hole 400A and Site 401 from overlying Late Cretaceous (Campanian) sediments, and at Hole 402A from overlying middle Eocene deposits (Figure 1). This hiatus corresponds with a distinct lithological change from the Lower Cretaceous organic-rich "black shale" facies to the light colored chalks and oozes of the Upper Cretaceous and lower Cenozoic.

\section{Lower Cretaceous}

Nannofossils are generally abundant in the Lower Cretaceous sediments, and dissolution-resistant species are enriched and well preserved. The more fragile forms are usually thin, partially broken, and etched, particularly at Hole $400 \mathrm{~A}$, where deposition occurred in deep water. Evidence for dissolution is more apparent in the black organic-rich layers, and is accompanied by an increase in relative abun- dance of radiolarians. Nannoconids are absent from the Lower Cretaceous sediments sampled at Hole 400A, but occur throughout much of the Aptian/Albian sequence at Hole 402A, where they are particularly abundant in the lower Aptian sediments, and at several horizons in the upper Aptian and Albian.

Planktonic foraminifers are abundant in the upper Albian sediments at Hole $400 \mathrm{~A}$, but are practically absent at Hole 402A, where sponge spicules, algae, and echinoid remains dominate (Dupeuble, this volume). Planktonic foraminifers are less abundant in the lower and middle-Albian deposits at Hole 400A, and are particularly rare in the dark organic-rich layers at both sites. However, they remain a significant component of the light colored layers at Hole 400A, while radiolarians become important in the dark layers. As with nannofossils, there appears to be a correlation between the presence of organic matter and the occurrence of extensive dissolution of foraminifers at Hole 400A. At Hole 402A planktonic foraminifers, and often also radiolarians, remain rare throughout the lower and middle Albian deposits, even in the light colored layers. In contrast, gastropod and pelecypod remains are common to abundant. Furthermore aragonitic benthic foraminifers (Epistominidae) occur throughout the Lower Cretaceous section at Hole 402A, but are absent at Hole 400A. This suggests that during Aptian/ Albian times Hole 402A was located above the aragonite compensation depth whereas Hole $400 \mathrm{~A}$ was situated below this level (Dupeuble, this volume).

Palynomorphs, of marine as well as of terrestrial origin, are common in the Aptian/Albian sediments (Davey, this volume). Dinoflagellate cysts are generally well preserved. The assemblages found at Hole 400A are comparable to those of onshore sections in France and England. Nominate species are rare at Hole $400 \mathrm{~A}$, and at this site the sequence could be dated only indirectly by comparison with the record from Hole 400A. The microspore assemblages are dominated by pollen grains of gymnospermous origin. Bisaccates are particularly abundant, but have only limited biostratigraphic value, whereas strongly sculptured triradiate spores are rare. In general, the preservation of the microspores is rather poor. Paleoenvironmental reconstructions based on the different fossil groups indicate that Hole $402 \mathrm{~A}$ was situated in a shelf environment, relatively close to land, whereas Hole 400A was located in a deeper basin, at greater distance from land, in Early Cretaceous times. A more detailed discussion of the Cretaceous paleoenvironment of these two sites is presented by de Graciansky et al. (this volume). The few centimeters of upper Aptian sediments recovered at Site 401 were probably deposited in an outer shelf to upper slope environment.

\section{Upper Cretaceous}

Upper Cretaceous sediments, of Campanian and Maestrichtian age, were recovered at Hole 400A and Site 401. At both sites the sediments contain abundant strongly broken calcareous nannofossils; differences between the assemblages at the two sites may be attributed to the differing paleoenvironments (Müller, this volume).

The different water depths at the two sites has also influenced the relative abundances of planktonic foraminifers. These are absent from the deep water sediments at Hole 
$400 \mathrm{~A}$, most probably because of dissolution, and it is concluded that this site was situated below the lysocline for planktonic foraminifers in Late Cretaceous time. In contrast, the upper Cretaceous sediments deposited at Site 401 are rich in well-diversified planktonic foraminiferal assemblages although some specimens show signs of dissolution, suggesting deposition at depths not far above this lysocline.

\section{Paleoceanographic Inferences}

Most of the biostratigraphic difficulties, enumerated above, are more or less directly attributable to a sequence of paleo-oceanographic events, which were either worldwide, or restricted to the North Atlantic Ocean.

Haq et al. (1977) have recently demonstrated profound latitudinal differentiation of the calcareous micro- and nannoplankton in the early Cenozoic Atlantic Ocean. These floral and faunal groups underwent major latitudinal shifts with time, which were attributed by these authors to major climatic fluctuations. Major episodes of warming were identified in the late Paleocene/mid Eocene and late Oligocene, and major episodes of cooling in the earliest Paleocene, mid Paleocene, mid Eocene, late Eocene/early Oligocene, and mid Oligocene.

Many of these proposed climatically controlled latitudinal shifts of nannoplankton and foraminiferal groups were not observed in the Leg 48 sediments. However, the studies of Haq et al. (1977) extended over a wide range of latitudes in the Atlantic Ocean, and both the Biscay and Rockall regions were areas occupied by their "coldest" foraminiferal association. In view of the non-quantitative nature of the Leg 48 faunal paleoenvironmental investigation, perhaps it is not surprising that many of the proposed fluctuations should be unresolvable at these sites. A brief summary of the major climatic changes identified from the faunal and floral content of these sediments is presented below.

\section{Nannoplankton Distribution}

Latitudinal differentiation of nannofossil assemblages is apparent in Leg 48 post-early Eocene sediment. This differentiation appears to have been more pronounced during the Paleogene, and to have undiminished in importance during the Neogene, when cool water nannoplankton assemblages dominated in both the Biscay and Rockall areas. Climatically induced changes in nannoplankton assemblages have been identified throughout the Paleogene and Neogene (Grazzini et al., this volume), and relatively warm periods correspond with nannoplankton Zones NP 9 to NP 10, upper part of NP 12 to NP 13, NP 17, NP 24, NN 3 to lower part of NN 7, lowermost NN 12 and NN 15. Additional distinct fluctuations in ambient water temperature have been identified within the upper Miocene sediments (Müller, this volume).

The strong dissolution of calcareous nannoplankton, and the lowering of surface water temperatures during the middle Eocene (NP 14-NP 16) may be attributed to the establishment of a link between the Atlantic and Arctic oceans at this time (Berggren and Hollister, 1974).

The occurrence of a few subtropical and tropical species in the late Oligocene (NP 24 and NP 25) in several parts of the North Atlantic indicates the penetration of warmer water masses to higher latitudes at this time. This is also the only period during which nannofossil ooze was deposited in the Norwegian-Greenland Sea, and the nannoplankton assemblages of this area correspond with those of the North Atlantic (Müller, 1976; Müller, this volume).

The almost complete extinction of discoasters within the upper part of nannoplankton Zone NN 16, together with the occurrence of the first ice-rafted material at this time, signifies the early stages of the northern hemisphere glaciation at about 2.7 m.y. B.P. (Berggren, 1972a; Müller, this volume).

\section{Foraminiferal Distribution}

The paleoceanographic-paleoclimatic imprint upon the biostratigraphy was even more pronounced for the foraminifers than for the calcareous nannoplankton, particularly during the Paleogene.

The Paleocene foraminiferal faunas of the Biscay sites were cosmopolitan and, as noted above, the fluctuations shown by Haq et al.(1977) were generally unobservable. However, strong latitudinal differentiation of faunas existed throughtout the Eocene and Oligocene between the Biscay Bay and Rockall areas.

The low latitude spinose and keeled globorotalids (morozovellids) that were abundant throughout the late Paleocene at Biscay were reduced to accessory components of the fauna during the earliest Eocene, and were replaced by mid-latitude spinose globigerinids (acarininids) and high latitude smooth globigerinids (subbotinids). At the same time the Rockall faunas were monotonously dominated by smooth globigerinids of the Globigerina linaperta group, and globorotalids occurred only sporadically. This basic faunal composition persisted throughout the Eocene, with the addition of common to abundant Globigerinatheca and Pseudohastigerina in both areas during the late middle and late-Eocene. The Oligocene faunas of both areas are dominated by specimens of the Globigerina tripartita- $G$. venezuelana group, but with the Biscay faunas having a larger complement of accessory species.

If the occasional appearances of keeled globorotalids in the Biscay area and of spinose globigerinids in the Rockall area are accepted as indicators of northward penetration of warm waters, then a few warm-cool fluctuations can be recognized. Warm episodes occurred during the time of foraminiferal Zones P.9, P.11 and possibly P.14. The timing of these warm episodes, however, does not coincide with the timing of the foraminiferal warm episodes of Haq et al. (1977), an observation which was also made for some of the nannofossil paleoclimatic trends.

Throughout the early-, middle-, and earliest late Miocene the foraminiferal faunas were of low diversity in both areas. Long-ranging, robust species dominate the faunas, with diagnostic index species occurring only as sporadic accessories. Such general faunal characteristics are typical of high latitude areas.

The late Neogene faunas continue to be dominated by long ranging globigerinids (G. pachyderma, G. bulloides, $G$. praebulloides, $G$. atlantica, etc.), but frequent, often abundant, occurrence of various globorotalid species increases the faunal diversity and at the same time provides the basis for biostratigraphic subdivision of this interval. 
The difference between the Rockall faunas and the Biscay faunas is one of species uniformity rather than species richness; globorotalids are more abundant towards the south. The effect of glacial-interglacial fluctuations upon the foraminiferal faunas could be recognized throughout the late Neogene. Glacial type faunas, which are the more common, are characterized in both areas by an increase in the dominance of $G$. pachyderma, G. quinqueloba, and $G$. bulloides at the expense of the globorotalids.

\section{PART II: CALIBRATION OF NORTH ATLANTIC LATE NEOGENE BIOSTRATIGRAPHIC ZONES BY MEANS OF PALEOMAGNETIC REVERSAL CHRONOLOGY AT HOLE 400A}

\section{Late Neogene Magnetic Polarity Time Scale}

The pattern and timing of geomagnetic field polarity reversals during the past $4.5 \mathrm{~m} . \mathrm{y}$. is now well established from combined paleomagnetic and radiometric dating studies of igneous rocks (Cox et al., 1963; McDougall and Tarling, 1963; Cox et al., 1964, 1967; Doell and Dalrymple, 1966; Chamalaun and McDougall, 1966; and Cox, 1969). During this interval there have been four major periods of near-constant polarity, designated the Brunhes normal, Matuyama reverse, Gauss normal, and Gilbert reverse polarity epochs, respectively. Each of these encompasses one or more short-period polarity "events" (Figure 3). The ages of most of these events, and of the boundaries between the four polarity epochs, have been reliably established by radiometric dating studies, but unfortunately the errors inherent in this dating technique prohibit its successful application to dating older polarity transitions (Cox, 1969). The extension, however, of this magnetic polarity time scale to earlier geological periods is possible from analyses of the linear magnetic anomalies that parallel the mid-ocean ridges in all ocean basins. Recognition that these anomalies are due to the recording of geomagnetic field reversals in newly formed oceanic lithosphere during the process of sea floor spreading (Vine and Matthews, 1963) allows the time of the field reversals to be established from the distance of the corresponding anomaly from the mid-ocean ridge, provided the rate of sea-floor spreading is known.

By assuming that the known rate of sea-floor spreading in the South Atlantic since the Gauss/Gilbert polarity transition (3.3 m.y.) had remained constant for the past 80 m.y., Heirtzler et al. (1968) were able to date all major polarity transitions throughout the Tertiary period, from the distance of successive anomalies from the Mid-Atlantic Ridge in the South Atlantic. Small modifications to the portion 0-10 m.y. of this time scale were proposed by Talwani et al. (1971), principally on the basis of a detailed analysis of a number of different magnetic profiles across the Reykjanes Ridge. Similarly, Blakely (1974) used signal-averaging techniques to analyze 14 magnetic profiles south of the Blanco fracture zone in the Northeast Pacific, and proposed minor amendments to the portion 7.4 to $22.7 \mathrm{~m} . \mathrm{y}$. of this scale.

The "standard" geomagnetic time scale used in the next section of this paper to calibrate the biostratigraphic sequence at Hole $400 \mathrm{~A}$ incorporates these amendments to the original Heirtzler et al. (1968) time scale.

\section{Late Neogene Magnetic Polarity Stratigraphy at Hole 400A}

In Figure 3 the paleomagnetic reversal sequence identified at Hole 400A (Hailwood, this volume) is plotted against the "standard" late Neogene polarity time scale discussed above. Although there are a number of breaks in the Hole 400A polarity record, due to coring gaps, or localized regions of deformed sediments which are unsuitable for paleomagnetic determinations, a reasonably unambiguous correlation with the standard polarity time scale is possible for the interval 70-220 meters sub-bottom. The paleomagnetic correlation points are indicated by crosses enclosed in circles, and the "error bars" attached to these points represent the maximum range of uncertainty in their position, due to coring gaps. This uncertainty follows from the fact that when a 9.5-meter DSDP core-barrel is only partly filled with sediment, the original position of the sediment within the core barrel is unknown. Consequently, the depth of the recovered sediment beneath the sea floor is subject to a maximum uncertainty equal to the length of missing sediment in that particular core barrel. It is reasonable to assume that in most cases coring gaps result from the drill-bit becoming "plugged" partway through drilling the core, and consequently the true depth beneath sea floor will be obtained by assuming that the sediment recovered was located at the top of that particular 9.5-meter cored interval. The paleomagnetic correlation points in Figure 3 are plotted on the basis of this assumption, but to allow for the fact that coring gaps could also sometimes be due to loss of material from the base of the core barrel during recovery, the maximum uncertainty in the depth determination is represented by the total length of unrecovered sediment in each core barrel.

The best-defined points in the correlation with the "standard" polarity time scale of Figure 3 are the Matuyama/Gauss and Gauss/Gilbert epoch boundaries. These occur at depths of 125 and 163 meters sub-bottom respectively, and consequently radiometric ages of 2.43 and 3.32 $\mathrm{m} . \mathrm{y}$. can be assigned to these two points. The Olduvai event, ranging from 1.71 to 1.86 m.y. (Talwani et al., 1971) appears to be well defined at a depth of 95 to 99 meters, and the underlying less well defined thin normal polarity zone at 106.5 meters, may possibly represent one of the "Reunion events." These were originally dated at 2.0 $\pm 0.1 \mathrm{~m} . \mathrm{y}$. by Chamalaun and McDougall (1966) and thought to be part of the Olduvai event, but there is now some evidence for their being separate and distinct events (e.g., Heirtzler et al., 1968; Emilia and Heinrichs, 1969; Cox, 1969; Opdyke, 1972). Since these events do not always appear in marine magnetic profiles or paleomagnetically studied sediment cores, they probably represent extremely short period reversals, or an effect of the nondipole field, having only local significance. Consequently, they have not been included in the "standard polarity time scale used in this paper.

Two short reverse polarity events are well defined at depths of 145 and 159 meters, respectively, within the Gauss epoch sediments at Hole 400A, and appear to correlate with the Kaena and Mammoth events, respectively. Similarly, four thin normal polarity zones between 195 and 215 meters sub-bottom show a good 


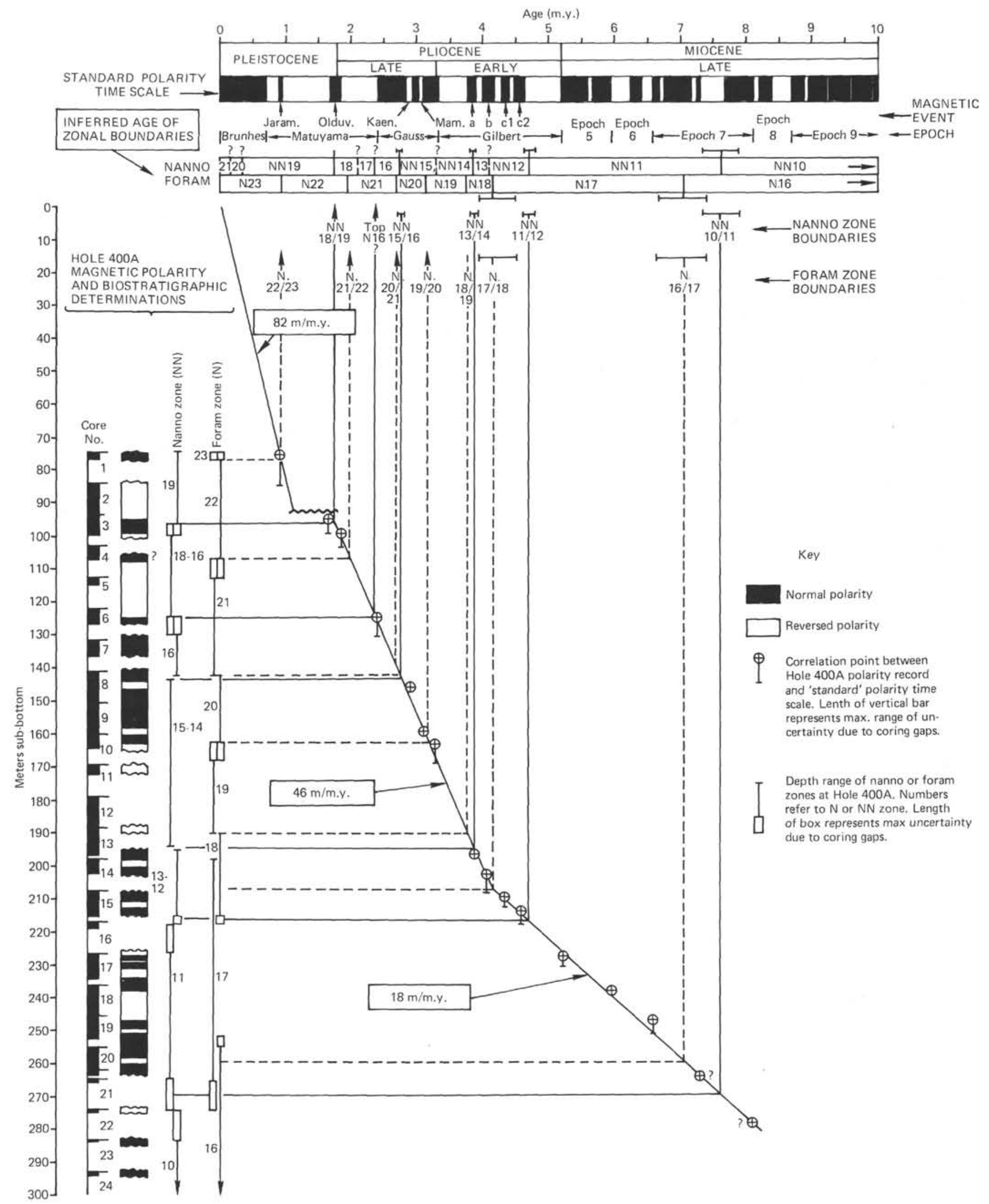

Figure 3. Proposed correlation between magnetic polarity record at DSDP Hole $400 \mathrm{~A}$ and "standard" polarity time scale for the past $10 \mathrm{~m} . \mathrm{y}$. This correlation is used as a basis for assigning "absolute" ages to the late Neogene nannofossil and foraminiferal zonal boundaries identified in Hole $400 \mathrm{~A}$. 
correlation with the four normal events within the Gilbert reverse epoch, at approximately $3.8,4.1,4.35$, and 4.55 m.y., respectively. Below a depth of 215 meters the combination of coring gaps and higher geomagnetic field reversal frequency renders identification of specific reversals more difficult, but a reasonably unambiguous correlation of magnetic epoch boundaries is possible down to the top of epoch $8(8.7 \mathrm{~m} . \mathrm{y}$.) at a depth of about 278 meters.

Three separate straight line segments may be fitted to these paleomagnetic correlation points, as indicated in Figure 3 , and indicate a change in sedimentation rate from 18 to 46 meters $/ \mathrm{m}$.y. at about $4.1 \mathrm{~m}$.y.B.P. (early Pliocene), and a second change from 46 to 82 meters $/ \mathrm{m} . \mathrm{y}$. in the early Pleistocene. This latter change is also marked by a short but significant hiatus representing a time interval of about $0.5 \mathrm{~m}$.y., close to the Pliocene/Pleistocene boundary.

\section{Use of Magnetostratigraphy to Calibrate Late Neogene Biostratigraphic Zones at Hole 400A}

By using the age-versus-depth calibration provided by the magnetostratigraphic correlation presented in Figure 3, it is possible to assign a numerical age to each of the principal late Neogene biostratigraphic zonal boundaries identified at this drill site. In this section the calibration of the calcareous nannoplankton, and planktonic foraminiferal zones will be discussed. The depth extent of each of these zones in Hole $400 \mathrm{~A}$ is shown by the vertical bars to the right of the downhole magnetic polarity record in Figure 3 . The numbers next to these bars refer to the corresponding Neogene nannoplankton (NN) zones of Martini (1971) or planktonic foraminiferal (N) zones of Blow (1969).

Although the standard calcareous nannoplankton zonation scheme of Martini (1971) can be used without difficulty for the Paleogene sediments at this site, the general decrease in oceanic water temperatures in this region throughout the Neogene (Grazzini et al., this volume) has resulted in scarcity or absence of most of the index fossils (Müller, this volume). This has led to difficulties in identifying some zonal boundaries, and in certain cases, two or more zones have had to be combined together, (e.g., nannozones NN 18-16, 15-14, and 13-12, Figure 4). However, due to the relative abundance of planktonic foraminifers at the site, each of the separate late Neogene planktonic foraminiferal zones of Blow (1969) could be identified.

The vertical "boxes" attached to the zonal depth-range bars in Figure 3 represent the maximum uncertainty in position due to coring gaps. In accordance with the convention used for the paleomagnetic determinations, the corresponding age of each zonal boundary is derived on the assumption that the top of the recovered sediment section in each core barrel was originally located at the top of that particular core. A more important source of uncertainty in the position of certain zonal boundaries is the overlap of adjacent zonal determination. The corresponding limits on the position of the zonal boundaries is shown by the horizontal error bars attached to the inferred ages of these boundaries in the figure.

Nannoplankton zonal boundaries NN 19/18, NN 16/15, and $\mathrm{NN} 12 / 11$ are each dated with a precision of $\pm(0.1$ to
$0.2) \mathrm{m} . \mathrm{y}$, whereas the boundary between Zones NN 11 and 10 has a slightly greater uncertainty of $\pm 0.3 \mathrm{~m} . \mathrm{y}$. The boundaries NN 21/20, NN 20/19, NN 18/17, NN 17/16, NN $15 / 14$, and NN 13/12 could not be located at this site due to coring gaps and/or the absence of diagnostic index fossils. Their positions have been inferred by interpolation between adjacent well-defined boundaries, and are subject to maximum uncertainty of $\pm 0.3 \mathrm{~m} . \mathrm{y}$.

In general the ages of foraminiferal zonal boundaries are specified with a precision of $0.1 \mathrm{~m} . \mathrm{y}$, but boundaries $\mathrm{N}$ $18 / 17$ and $N \quad 17 / 16$ are more poorly specified with an uncertainty of about \pm 0.3 m.y.

\section{PART III: REVISION OF 'STANDARD' PALEOGENE AND EARLY NEOGENE MAGNETIC POLARITY TIME SCALE}

\section{Introduction: Previous Paleogene Polarity Scales}

The first attempt at dating the sequence of Paleogene geomagnetic field reversals was based on their identification in the representative magnetic profile from the South Atlantic analyzed by Hiertzler et al. (1968), who assumed that the rate of sea-floor spreading at this location for the past $3.3 \mathrm{~m} . \mathrm{y}$. $(1.9 \mathrm{~cm} / \mathrm{yr})$ had remained constant since Late Cretaceous times. Since its publication, the Heirtzler et al. (1968) time scale has been widely accepted although several authors have noted that the extrapolation of a constant spreading rate in the South Atlantic from $3.3 \mathrm{~m}$.y. to 80 m.y. B.P. may have led to significant errors in the older part of this time scale. Sclater et al. (1974) examined the biostratigraphic ages of the oldest sediments recovered from DSDP sites with good basal sediment-basement contacts, drilled on identifiable magnetic anomalies. They note that for some anomalies older than number 13 the magnetic anomaly age according to the magnetic time scale of Heirtzler et al. (1968) is consistently 5 to $8 \mathrm{~m}$.y. older than the biostratigraphic age of the oldest sediments. An upward revision of the ages of Paleogene anomalies is inferred, such that the age of anomaly 24 would be about $56 \mathrm{~m}$.y., i.e., some $4 \mathrm{~m}$.y. younger than the value deduced by Heirtzler et al. (1968).

A more drastic revision was proposed by Tarling and Mitchell (1976), principally on the basis of revised glauconite ages from European Eocene sediments and the biostratigraphic correlation between the oldest sediments overlying anomaly 24 at DSDP Site 39 , and sediments intercalated with the plateau basalts of East Greenland (Soper et al. 1976). A mean radiometric age of 49 m.y. was derived for the upper part of these basalts by Hailwood et al. (1972), and accordingly, Tarling and Mitchell (1976) infer that this must be the age of anomaly 24 . However, the age determinations on these basalts include a range from 47 to $52 \mathrm{~m} . \mathrm{y}$., with no apparent stratigraphic relationship between the different values (e.g., an age of $48 \mathrm{~m}$.y. was derived for one lava flow at Scoresby Sund, and an age of $50 \mathrm{~m} . \mathrm{y}$. for a flow some $1.5 \mathrm{~km}$ higher). It is therefore proposed here that the older extreme value of $52 \mathrm{~m} . \mathrm{y}$. is likely to represent a more realistic estimate for the age of the upper part of the basalt pile, and also the start of anomaly 24. This age is in good agreement with the revised Paleogene polarity time scale presented below. 


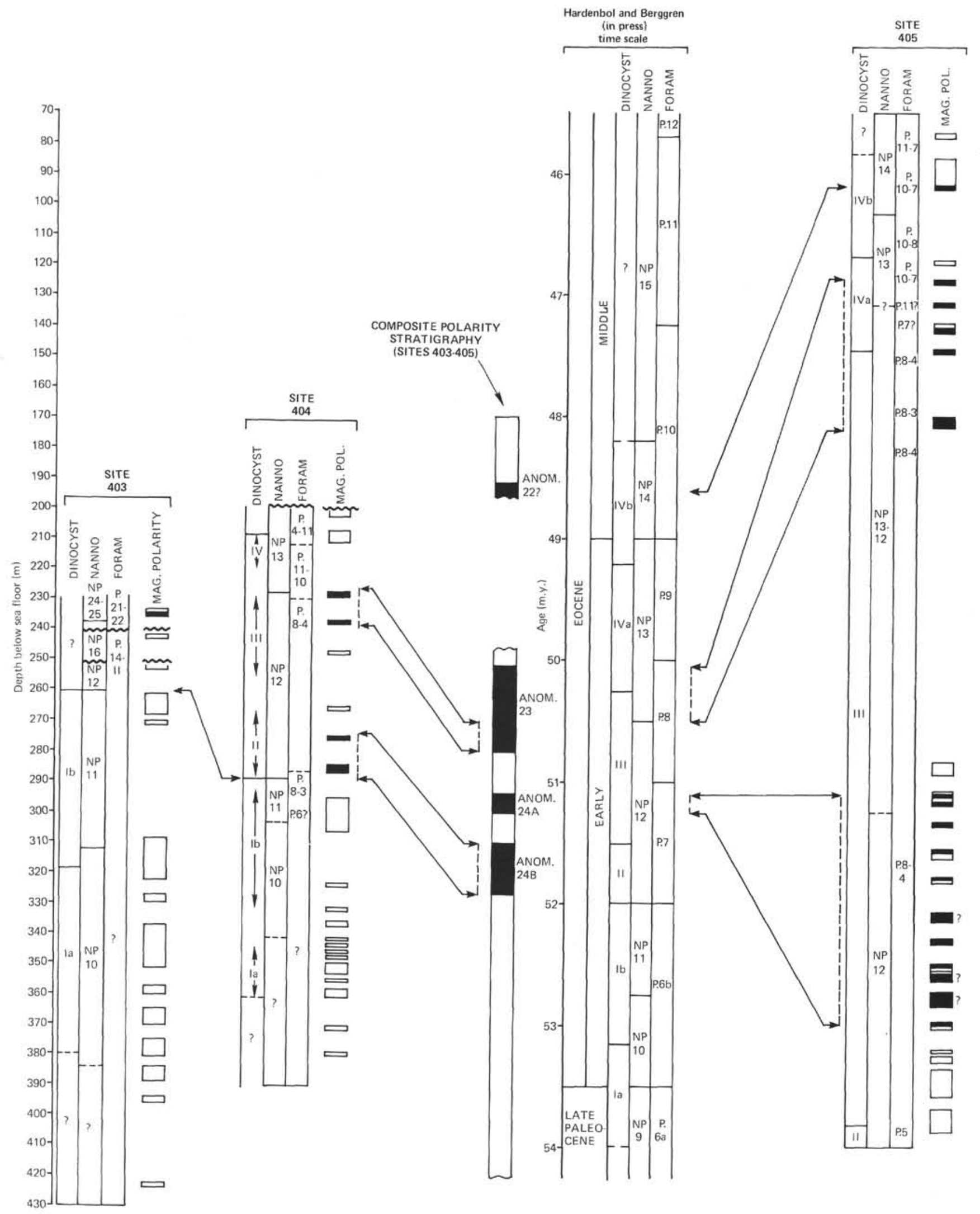

Figure 4. Summary of magnetic polarity and biostratigraphic determinations at Sites 403, 404, and 405 (Rockall Plateau), and development of composite polarity stratigraphy (central column). 


\section{Paleomagnetic Data From IPOD Sites 403 to 405}

A summary of the paleomagnetic determinations from IPOD Sites 403 to 405 , located at the southwest margin of the Rockall plateau, is shown in Figure 4. Because planktonic foraminiferal zones at these sites could not be determined very precisely, the ensuing discussion is based primarily on the biostratigraphy provided by nannofossils (Müller, this volume) and dinocysts (Costa and Downie, this volume).

Site 403 was situated on the rifted westerly margin of Rockall, some $30 \mathrm{~km}$ east of marine anomaly 24 , and at this site a thick Paleocene/Eocene sequence of volcanogenic siltstones and glauconitic mudstones, of deltaic aspects, was recovered. Paleomagnetic measurements on these sediments (Hailwood, this volume) reveal a reverse polarity throughout (left-hand set of columns in Figure 4), and biostratigraphic determinations suggest that the minimum length of this reverse polarity interval is between 2.0 and $2.5 \mathrm{~m} . \mathrm{y}$. The relationship of the site location to the position of anomaly 24, the oldest identifiable anomaly in the northeast Atlantic, and also the interpretation of seismic refraction profiles through this site (Roberts, this volume), suggests that this sedimentary prism was deposited during the very early stages of separation of Rockall from East Greenland. Consequently there can be little doubt that the long reversely magnetized section of sediments identified at Site 403 corresponds with the long episode of reverse polarity known to precede anomaly 24 (Heirtzler et al., 1968, and Figure 5). A similar sequence of volcanogenic siltstones was encountered at nearby Site 404 , which is situated in a tectonic environment similar to Site 403 . The lower half of the Paleogene sedimentary section recovered from Site 404 was also reversely magnetized, and belongs to the same biostratigraphic zones (Nannozones NP 10 and 11 , and dinocyst Zones $\mathrm{Ia}$ and $\mathrm{Ib}$ ) as the reverse polarity sediments of Site 403 (Figure 4). Consequently they are also assigned to the long reverse polarity episode which precedes anomaly 24 . The oldest normal polarity sediments encountered at Site 404 lie at the base of nannofossil Zone NP 12, and within dinocyst Zone II of Costa and Downie (this volume), and this is accordingly considered to represent the biostratigraphic age of the start of anomaly 24 . This anomaly consists of two separate normal polarity episodes (Heirtzler et al., 1968), designated $24 A$ and $24 B$ in Figure 4; comparison of the paleomagnetic data from all three DSDP Rockall sites suggests that the whole of the lower normal polarity interval at Site 404 may be correlated with anomaly $24 B$. From this starting point, a simultaneous comparison of the overlying magnetic polarity stratigraphy and biostatigraphic zones at Sites 404 and 405 allows the establishment of the composite reversal sequence shown in the central column of this figure, which extends from anomaly $24 B$ to anomaly 23 , and possibly also includes the upper part of anomaly 22 . The present study provides reliable estimates of the biochronologic age of each of these anomalies, and thus important new calibration points for the Paleogene magnetic polarity time scale (see next section).

\section{Revised Paleogene Polarity Time Scale}

Figure 5 represents a compilation of available information on the ages of Cenozoic magnetic anomalies. The sequence of anomalies originally deduced by Heirtzler et al. (1968) is plotted along the upper horizontal axis of this diagram, and more recent information on the ages of certain anomalies, including that discussed above from Sites 403 to 405 , is used to modify this scale, and produce the revised polarity time scale plotted along the vertical axis. The numerical ages assigned to the biostratigraphic time scale in this figure have been derived from three separate sources. For the period $0-10 \mathrm{~m} . \mathrm{y}$. the ages of zonal boundaries proposed for the North Atlantic region in Part II of this chapter have been used, whereas for the period 10-24 m.y. the biostratigraphic time scale is that of Ryan et al. (1974), deduced primarily from combined paleomagnetic and biostratigraphic studies of sedimentary stratotypes in Italy. For the period 24 to $65 \mathrm{~m}$.y. the recently published Paleogene biostratigraphic time scale of Hardenbol and Berggren (in press) is used.

In the revised polarity time scale shown in Figure 5, the ages of anomalies in the interval 0 to $23 \mathrm{~m}$.y. have been modified directly from the Heirtzler et al. (1968) time scale, utilizing the data of Talwani et al. (1971) and Blakely (1974), discussed in Part II of this chapter. Each of the vertical bars through which the correlation line is drawn in this diagram represents the biostratigraphic age of the anomaly shown numbered next to the bar. These ages have been derived from the paleontological studies of basal sediments at DSDP sites which were drilled on identifiable marine magnetic anomalies, and at which a reliable biochronological age has been obtained for the sediment-basement contact. For the interval 0 to $23 \mathrm{~m}$.y. the correlation line passes through four of the six data points available, but at the other two sites (36 and 396) the biostratigraphic age of the basal sediments is significantly older than the inferred age of the corresponding anomaly. This disagreement is disturbing, but in view of the fact that the age of the two anomalies (numbers 4 and 5) agrees with the correlation line at Sites 395 and 16 (Figure 5), the most likely explanation is that these anomalies have been misidentified at Sites 36 and 396.

Additional correlation points are available for the ages of anomalies 22, 23, 24A and $24 B$, from the Paleogene magnetic biostratigraphic results for Sites 403 to 405 described in the previous section. Similarly, the biostratigraphic ages of anomalies 25 to 29 have been determined from magnetobiostratigraphic studies of the Late Cretaceous to Paleogene scaglia of the Gubbio section, Italy (Premoli-Silva et al., 1974). These correlation points are shown by the small shaded boxes in Figure 5, and the adjacent numbers refer to the corresponding magnetic anomaly.

It is clear that these data points do not lie close to a single straight line passing through the origin, as would be expected if they were compatible with the Heirtzler et al. (1968) time scale. Instead, they lie on three separate straight line segments, with changes of gradient occurring 


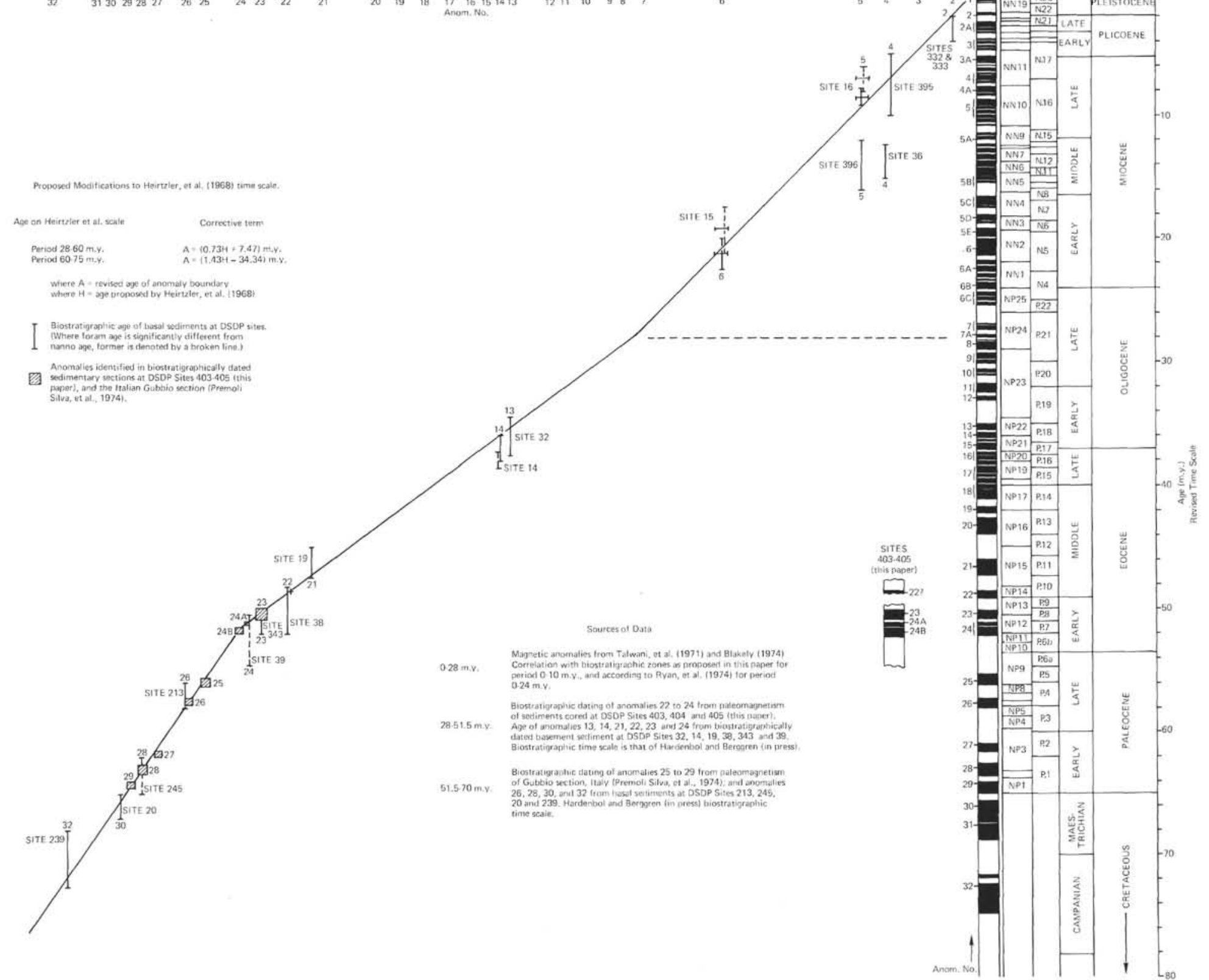


approximately at the time of anomalies $24 B$ and $7 A$. This implies that the assumption by Heirtzler et al. (1968) of a constant spreading rate at the location of their reference magnetic profile V-20 in the South Atlantic is incorrect, and that significant changes in spreading rate occurred in the

TABLE 1

Revised Cenozoic Time Scale

\begin{tabular}{|c|c|c|c|}
\hline \multicolumn{4}{|c|}{ Intervals of Normal Polarity (m.y.) } \\
\hline Period & Anom. No. & Period & Anom. No. \\
\hline $0.00-0.69$ & 1 & $23.29-23.40$ & \\
\hline $0.89-0.95$ & \multirow{4}{*}{2} & $23.63-24.07$ & $6 \mathrm{~B}$ \\
\hline $1.71-1.86$ & & $24.41-24.59$ ) & \multirow{3}{*}{$6 \mathrm{C}$} \\
\hline $2.43-2.84$ & & $24.82-24.97$ & \\
\hline $2.94-3.04$ & & $25.25-25.43 J$ & \\
\hline & \multirow[t]{3}{*}{$2 \mathrm{~A}$} & $26.86-26.98\}$ & \\
\hline $3.10-3.32 \mid$ & & $27.05-27.37\}$ & 7 \\
\hline $3.78-3.887$ & & $27.83-28.03$ & $7 \mathrm{~A}$ \\
\hline $\left.\begin{array}{l}4.01-4.17 \\
4.31-4.41\end{array}\right\}$ & \multirow[t]{2}{*}{3} & $\begin{array}{l}28.26-28.32 \\
28.38-28.98\end{array}$ & 8 \\
\hline $4.48-4.66]$ & & $29.31-29.77$ & \\
\hline $4.18-5.58\}$ & \multirow{4}{*}{$3 \mathrm{~A}$} & $29.82-30.15\}$ & 9 \\
\hline $5.66-5.94\}$ & & $30.57-30.82]$ & \multirow{3}{*}{10} \\
\hline $6.26-6.39$ & & $30.86-31.06\}$ & \\
\hline $6.59-6.68$ & & $31.78-32.07\}$ & \\
\hline $6.75-7.17\}$ & \multirow{3}{*}{4} & $32.11-32.45\}$ & 11 \\
\hline \multirow{4}{*}{$\left.\begin{array}{l}7.24-7.30 \\
7.69-8.11 \\
8.21-8.37 \\
8.71-8.88 \\
8.93-9.27\end{array}\right\}$} & & $32.78-33.13$ & 12 \\
\hline & & $\begin{array}{l}35.05-35.20 \\
35.25-35.52\end{array}$ & \multirow{2}{*}{13} \\
\hline & \multirow[t]{2}{*}{$4 \mathrm{~A}$} & $\begin{array}{l}35.25-35.52\} \\
35.83-35.90\end{array}$ & \\
\hline & & $35.94-36.01\}$ & \multirow[t]{2}{*}{14} \\
\hline $9.28-9.58\}$ & \multirow[t]{5}{*}{5} & & \\
\hline $9.61-9.91$ & & $36.63-36.80$ | & \multirow{4}{*}{15} \\
\hline $9.93-10.21)$ & & $36.82-36.98\}$ & \\
\hline $10.34-10.40$ & & & \\
\hline $10.88-10.95$ & & $37.32-37.51]$ & \\
\hline $11.47-11.66\}$ & \multirow{5}{*}{$5 \mathrm{~A}$} & $37.64-37.87\}$ & \multirow[t]{2}{*}{16} \\
\hline $11.80-12.09\}$ & & $37.91-38.24 J$ & \\
\hline $12.46-12.50$ & & $38.47-39.19$ & \multirow{3}{*}{17} \\
\hline $12.59-12.65$ & & $39.25-39.41\}$ & \\
\hline $12.88-13.08$ & & $39.47-39.74$ & \\
\hline \multirow{4}{*}{$\left.\begin{array}{l}13.30-13.58 \\
13.84-14.28 \\
14.40-14.91 \\
15.13-15.24 \\
15.42-15.57\end{array}\right\}$} & \multirow[b]{4}{*}{$5 B$} & $\begin{array}{l}39.89-40.24 \\
40.30-40.64\end{array}$ & \\
\hline & & $\left.\begin{array}{l}40.30-40.64 \\
40.70-41.05\end{array}\right\}$ & 18 \\
\hline & & $41.76-42.12$ & 19 \\
\hline & & $42.60-43.83$ & 20 \\
\hline $16.63-16.96)$ & \multirow{3}{*}{$5 \mathrm{C}$} & $45.90-47.18$ & 21 \\
\hline $17.00-17.19\}$ & & $48.47-49.02$ & 22 \\
\hline $17.27-17.47 J$ & & $50.03-50.69$ & 23 \\
\hline $18.12-18.49$ & \multirow[t]{2}{*}{$5 \mathrm{D}$} & $51.05-51.24\}$ & \multirow[t]{2}{*}{24} \\
\hline $18.72-18.75$ & & $51.47-52.10$ & \\
\hline $19.22-19.80$ & $5 \mathrm{E}$ & $55.30-56.06$ & 25 \\
\hline $20.11-21.31$ & \multirow[t]{2}{*}{6} & $57.29-57.97$ & 26 \\
\hline $21.79-22.09$ & & $60.87-61.51$ & 27 \\
\hline $22.34-22.69$ & \multirow[t]{2}{*}{$6 \mathrm{~A}$} & $62.47-63.53$ & 28 \\
\hline $22.90-23.08$ & & $64.00-64.86$ & 29 \\
\hline
\end{tabular}

Note: 0 - 8.7 m.y. - Talwani et al. (1971); 8.7 - 22.7 m.y. Blakely (1974); 22.7 - 28 m.y. - Heirtzler at al. (1968) 28.0 - 60.0 m.y. - Heirtzler et al. (1968), modified according to $\mathrm{A}=(0.73 \mathrm{H}+7.47)$ m.y.; 60.0 - 75.0 m.y. Heirtzler et al. (1968), modified according to $A=(1.43 \mathrm{H}$ - 34.34) m.y. where $A=$ revised age, and $H=$ age proposed by Heirtzler et al. (1968). early Eocene at the time of anomaly 24, and again in the late Oligocene at about the time of anomaly $7 \mathrm{~A}$.

The ages of the intervals of normal magnetic polarity on this revised Cenozoic time scale are listed in Table 1. For the period 28 to $65 \mathrm{~m} . \mathrm{y} . \mathrm{B}$. .P. these have been calculated directly from the Heirtzler et al. (1968) time scale, using the equations for the two appropriate straight line segments derived from Figure 5.

Age of Anomaly 24, and the Opening of the Northeast Atlantic

The new Cenozoic polarity time scale is plotted on a larger scale in Figure 6, together with biostratigraphic zonal ranges. It is significant that on this new scale the age of the start of anomaly 24 is $52 \mathrm{~m}$.y. This numeric age is derived principally from the radiometric ages of authigenic glauconite in the sedimentary formations used by Hardenbol and Berggren (in press) to calibrate their Paleogene biostratigraphic time scale. An independent early Paleogene radiometric calibration point, however, is available through biostratigraphic studies of the radiometrically dated Paleogene basalts of East Greenland. On the basis of palynological studies of sediments intercalated with these basalts, Soper et al. (1976) demonstrate that they were erupted during the time of dinocyst Zones Ia and the early part of Zone Ib. According to the biostratigraphic correlation presented in Part V of this chapter (Figure 2), this interval corresponds with the late part of Nannozone NP 9 through to the end of NP 10 (Figure 6). The sediments overlying these basalts at Cap Dalton were dated by Soper et al. (1976) as close to the dinocyst Zone II/III boundary, i.e., the early part of Nannozone NP 12. The period of eruption of these basalts may therefore have extended from the late part of Nannozone NP 9 through to the end of NP 11.

This inferred age range for the emplacement of the East Greenland basalts is consistent with the reversed magnetic polarity observed throughout the basalt sequence (Hailwood et al., 1972; Faller, 1975), and with their eruption during the long reverse polarity interval that preceded anomaly 24 (Figure 6). The radiometric age of approximately $52 \mathrm{~m} . \mathrm{y}$. for the upper part of these basalts is therefore compatible with the revised polarity time scale presented in Figure 6, in which the top of Nannozone NP 11 corresponds with an age of $52 \mathrm{~m} . \mathrm{y}$.

The calibration point provided by the East Greenland basalts is important, since at present it represents the only available early Paleogene radiometrically dated marine biostratigraphic reference level that is not based on a glauconite age.

In summary, the new Cenozoic magnetobiostratigraphic time scale presented in Figure 6 appears to provide the best agreement with all currently available constraints. According to this new time scale the age of the oldest identifiable marine magnetic anomaly (number 24) in the northeast Atlantic is $52 \mathrm{~m} . \mathrm{y}$. (early Eocene), and this must correspond closely with the date of initiation of sea-floor spreading between Rockall and Greenland. This age is significantly different from the values of $60 \mathrm{~m}$.y. proposed by Heirtzler et al. (1968), 56 m.y. by Sclater et al. (1974), and 49 m.y. by Tarling and Mitchell (1976). 

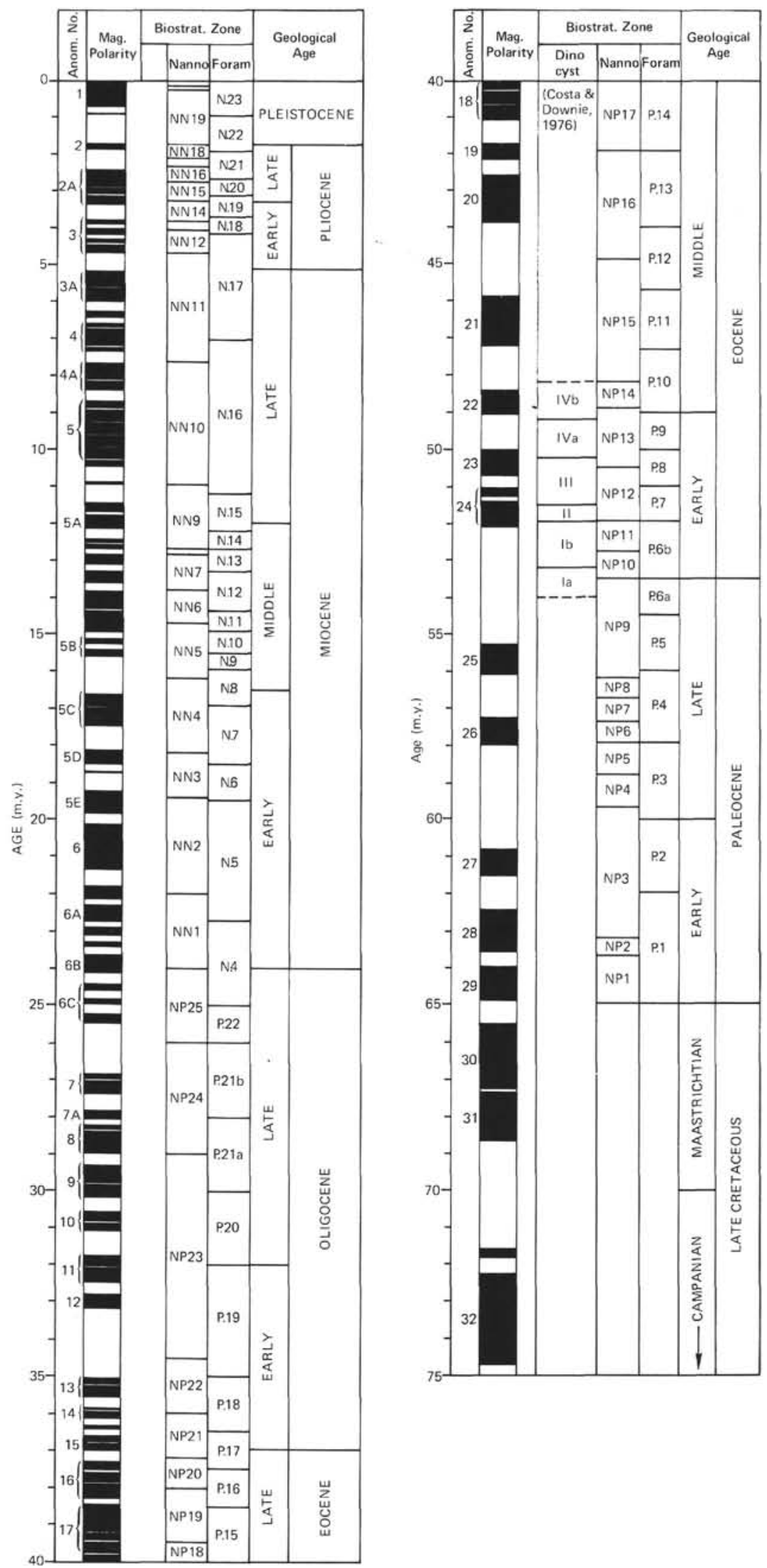

Figure 6. Detailed correlation of revised Cenozoic polarity time scale to biostratigraphic scale of Hardenbol and Berggren (in press). 


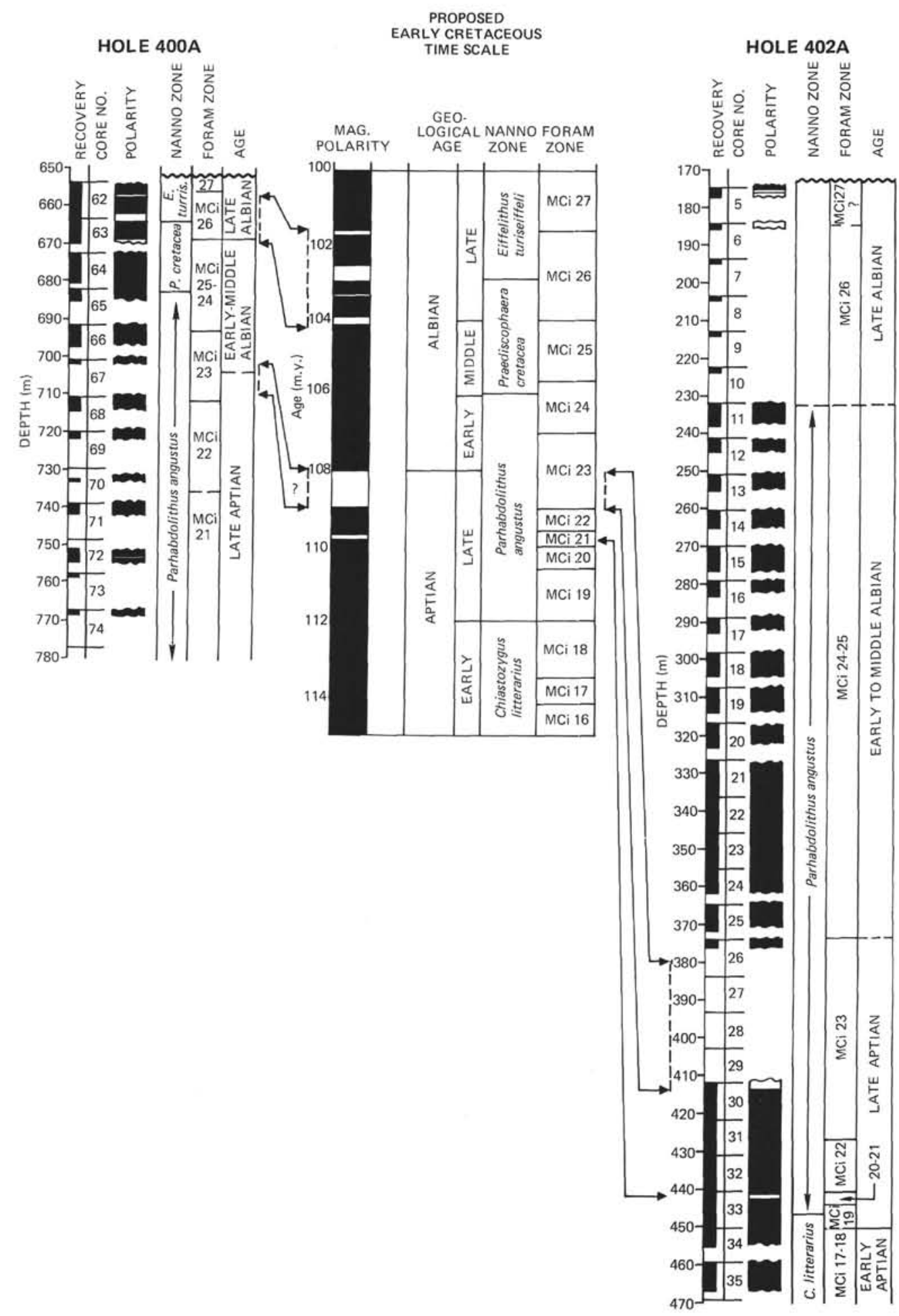

Figure 7. Development of Early Cretaceous polarity time scale from magneto-biostratigraphic determinations at Holes $400 \mathrm{~A}$ and $402 \mathrm{~A}$. 
Figure 1 shows a lithological summary of the sediments recovered at each of the seven sites drilled in the Bay of Biscay and Rockall Plateau during DSDP Leg 48. An important feature of this record is the conspicuous change in lithology from terrigenous to biogenic siliceous and calcareous sediments at about $50 \mathrm{~m}$.y. This change appears to follow soon after the initial separation of Greenland from Rockall at $52 \mathrm{~m} . \mathrm{y}$. , and may possibly be related to the establishment of a continuous link between the Atlantic and Arctic oceans at this time. This connection may have resulted in the change from the warm-water planktonic foraminiferal fauna of the Paleocene and earliest Eocene to the mid- and high latitude "cool water"' faunas that characterized the marine parts of this region for the remainder of the Paleogene. It is also possible that the change in lithology at about $50 \mathrm{~m}$.y. was influenced by the development of the western English Channel from a large bay into a continuous strait connecting with the North Sea region at this time (D. Curry, personal communication).

\section{PART IV: CRETACEOUS MAGNETOSTRATIGRAPHY}

At Holes 400A and 402A in the northeast Bay of Biscay, thick sequences of Cretaceous carbonaceous mudstones, spanning the Aptian and Albian stages, were recovered, and combined paleomagnetic-biostratigraphic studies of these sediments allow useful constraints to be placed on parts of the Cretaceous polarity time scale.

The magnetostratigraphic and biostratigraphic sequences from these two sites are summarized in the two outer columns of Figure 7. A conspicuous feature of the paleomagnetic results is the dominance of normal magnetic polarities throughout these sediments. This is consistent with their deposition during the long Cretaceous interval of dominantly normal polarity, which extended over a total interval of some $40 \mathrm{~m} . \mathrm{y}$. from the Barremian to the Santonian (e.g., Larson and Hilde, 1975). Within this long normal polarity period two separate reverse polarity periods have been proposed.

\section{Anomaly $\boldsymbol{M}-\boldsymbol{O}$}

The oldest reverse polarity interval, located close to the Aptian/Albian boundary, has been identified in Mesozoic sediments in the U.S.S.R. (Pechersky and Khramov, 1973) and was designated the "Gatan" event by these authors. Subsequently it has been correlated with marine anomaly $M-O$, and its duration has been estimated as 1 to $2 \mathrm{~m} . \mathrm{y}$. (e.g., Larson and Hilde, 1975; van Hinte, 1976). This event, however, was not positively identified at either Hole $400 \mathrm{~A}$, or $402 \mathrm{~A}$ on DSDP Leg 48 (Figure 7).

Evidence in support of a late Aptian age for anomaly $M-O$ includes its position on the marine magnetic profiles for the Hawaiian area published by Larson and Hilde (1975). Assuming a uniform rate of sea-floor spreading in this area throughout the Cretaceous, and extrapolating the biostratigraphic ages for anomalies $M-7 / M-8$ and $M-24 / M-25$, obtained from basal sediments overlying these anomalies at DSDP Sites 166, 105, and 100, they derive an age of mid- to late-Aptian for anomaly $M-O$. This corresponds with a numeric age of 108 to $109 \mathrm{~m} . \mathrm{y}$. on the Geological Society of London time scale (Harland et al., 1964). More direct evidence has been derived from DSDP Hole 417D, drilled on top of this anomaly, in the North Atlantic. The sediments immediately overlying basement at this site are dated by nannofossils as late Aptian (DSDP Leg 51 Scientific Party, 1977), but as yet no specific biostratigraphic zone has been published.

In view of the above evidence, the existence of marine anomaly $M-O$ appears to be well established, and its age is reasonably well specified as late Aptian. Consequently its absence in the sedimentary records from Holes 400A and $402 \mathrm{~A}$ (Figure 7) is somewhat surprising. On the basis of foraminiferal zones, the average rates of sedimentation for the Albian/Aptian sediments at these two sites are $8 \mathrm{~m} / \mathrm{m} . \mathrm{y}$. and $36 \mathrm{~m} / \mathrm{m} . \mathrm{y}$., respectively. Assuming the duration of anomaly $M-O$ to be $1 \mathrm{~m} . y$., the corresponding length of reverse polarity sediment to be expected at Holes $400 \mathrm{~A}$ and $402 \mathrm{~A}$ is 8 meters and 36 meters, respectively. Coring gaps of this length are present at both sites, within sediments belonging to the MCi 23 (Ticinella bejaouaensis) foraminiferal zone, and Parhabdolithus angustus nannofossil zone. Furthermore, reversed magnetic polarities were identified in the uppermost two samples beneath the coring gap at Hole 402A. On the basis of this evidence it is tentatively proposed that the age of marine anomaly $M-O$ corresponds with the lower part of foraminiferal Zone MCi 23.

Other thin reverse polarity zones were identified beneath this level, within foraminiferal Zone MCi 21 at both sites. Using the biostratigraphically determined sedimentation rate of 36 meters/m.y., the maximum duration of the event at Hole $402 \mathrm{~A}$ is approximately 50,000 years. It is possible that the same short pre- $M-O$ event has been recorded at both sites, but in view of the relatively large coring gaps this would seem an unlikely coincidence. It is more probable that a number of very short-period reversals, with a time scale of $\sim 10^{4}$ years occurred during the late Aptian, and that different ones have been identified at the two sites. Nonetheless, this short-period structure of the geomagnetic polarity time scale may prove to be valuable in defining " marker horizons" within rapidly and continuously deposited late Aptian sedimentary sequences.

\section{Late Albian Mixed Polarity Interval}

A number of relatively short period reversals, of average duration $0.2 \mathrm{~m} . \mathrm{y}$. were also identified within the late Albian sediments at Holes 400A and 402A (Figure 7). These appear to show a good correlation with the late Albian " "mixed polarity interval"' identified by Green and Brecher (1974) and Jarrard (1974) at DSDP Site 263. The relatively precise biostratigraphic dating of these reversals at Hole $400 \mathrm{~A}$, allows their confident assignment to the nannofossil zone Eiffellithus turriseiffeli and the end of the Praediscosphaera cretacea Zone, and to the foraminiferal Zone $\mathrm{MCi}$ 26 (Ticinella breggiensis) of Sigal (1977).

The resultant Cretaceous magnetic polarity stratigraphy proposed from the Leg 48 studies is shown in the central column of Figure 7. 


\section{PART V: CORRELATION BETWEEN NORTHEAST ATLANTIC FORAMINIFERA, NANNOPLANKTON AND DINOCYST ZONES}

\section{Paleogene}

The correlation between planktonic foraminifers and calcareous nannoplankton zones identified in the Leg 48 material shows general agreement with the "standard" low-latitude zonal scheme of Hardenbol and Berggren (in press). Nevertheless a few apparently significant departures from this scheme were observed, and these are commented on below.

In Figure 8 the age ranges of the Paleogene planktonic foraminiferal zones, according to the Hardenbol and Berggren (in press) time scale, are plotted in the left-hand column. The ranges of the calcareous nannoplankton zones are also shown, positioned according to the different correlations of Hardenbol and Berggren (in press), Berggren (1972a-c), Martini (1970), and the present study. It is important to note that the time-normalization for each of the nannoplankton zone scales shown is derived from the ages of the corresponding foraminiferal zones on the Hardenbol and Berggren (in press) time scale. Consequently the numeric ages of the nannoplankton zone boundaries for the Berggren (1972a-c) and Martini (1970) scales in this diagram are generally different from those originally proposed by these authors.

Well-defined nannofossil zone boundaries identified from the present study are depicted by solid lines in Figure 8, and poorly-defined boundaries by broken lines. The NP 24/25 nannozone boundary correlates with the P.21/22 foraminiferal zone boundary, in agreement with the Hardenbol and Berggren (in press) time scale. Similarly, good agreement with this scale is apparent for the NP 17/18, NP $14 / 15$, NP $12 / 13$, NP $11 / 12$, NP $9 / 10$, and NP $7 / 8$ nannofossil boundaries. The most significant discrepancy with the Hardenbol and Berggren (in press) time scale is in the position of nannozone boundary NP 23/24. According to the latter scale, this boundary should lie towards the middle of the P.21a foraminiferal zone, whereas in the present study it corresponds more closely with the center of the P. 20 foraminiferal zone. This position is similar to that proposed by Martini (Figure 8). Similarly the position of the NP $16 / 17$ nannozone boundary is in better agreement with the Martini (1970) time scale than the Hardenbol and Berggren (in press) scale.

The differences between the zonation schemes established for the northeast Atlantic in the present study, and the low-latitude zonation scheme of Hardenbol and Berggren (in press) may be attributed, at least in part, to the ecological factors discussed in the first section of this paper. The general agreement, however, in position of boundaries between key nannofossil Zones NP 11 to NP 15 in the Leg 48 sediments (Figure 8 ) and in the low latitude section of Hardenbol and Berggren (in press) provides some confidence in the use of the biostratigraphically determined ages of magnetic anomalies 22 to 24 at Sites 403 to 405 as part of the basis for recalibrating the Paleogene polarity time scale (Figure 5).

\section{Late Neogene}

The age of the late Neogene calcareous nannofossil and planktonic foraminiferal zones determined at Hole 400A are compared with the zonal range charts of Berggren (1972), Ryan et al. (1974), and Berggren and Amdurer (1973) in Figure 9. Because the positions of the northeast Atlantic zonal boundaries (Part II of this paper) and Mediterranean zonal boundaries (Ryan et al., 1974) were both determined by recourse to magnetic polarity stratigraphy, they are theoretically referred to an "absolute" time scale, assuming magnetic reversals to be essentially synchronous and worldwide in extent. Consequently it is instructive to compare the positions of the zonal boundaries in these two regions.

In the northeast Atlantic the NN 22/23 nannofossil zone boundary, which is commonly taken to represent the upper limit of the early Pleistocene (e.g., Berggren and Amdurer, 1973), corresponds closely with the position of the Jaramillo event, at 0.90 m.y. B.P. In the Mediterranean sections studied by Ryan et al. (1974) this zonal boundary was located close to the Brunhes/Matuyama epoch boundary, at 0.70 m.y. B.P. (Figure 9). Other well-defined Pleistocene and uppermost Pliocene zonal boundaries, such as the N.21/22 foraminiferal, and NN 18/19 nannofossil zone boundaries, also appear to be systematically older in the northeast Atlantic than in the Mediterranean. Prior to about 2.5 m.y. B.P. the situation appears to be reversed, and zonal boundaries in the Mediterranean (e.g., N.18/19, N.17/18, N.16/17, NN 11/12, and NN 10/11) are generally older than their counterparts in the northeast Atlantic. In view of possible uncertainties in some of the zonal determinations this observation presently must be treated as tentative. Reasons for pre- 2.5 m.y. zonal boundaries appearing to be older in the Mediterranean are not immediately apparent. It is possible that the change in environment inferred at about $2.5 \mathrm{~m} . \mathrm{y}$. B.P., which resulted in earlier extinction of species in the northeast Atlantic than the Mediterranean region, may be related to the commencement of the northern hemisphere glaciation at about this time. The cooling effects of polar ice sheets would be greater in the northeast Atlantic, and are clearly seen in the Leg 48 sediments by the almost complete extinction of the discoasters at about 2.5 m.y. B.P., and the appearance of ice-rafted material in sediments of this age. A more detailed discussion of Cenozoic North Atlantic paleoceanography is presented by Grazzini et al. (this volume).

\section{CONCLUSIONS}

Combined paleomagnetic and biostratigraphic studies of the Cretaceous and Cenozoic sediments from the Bay of Biscay and Rockall Plateau cored on DSDP Leg 48, allow the calibration of the northeast Atlantic late Neogene biostratigraphic zones against the magnetic polarity time scale. On the basis of this calibration an "absolute" numeric age can be assigned to each of the major zonal boundaries, and comparison with the paleomagnetically dated biostratigraphic zonal boundaries for the Mediterranean deduced by Ryan et al. (1974), reveals some interest- 


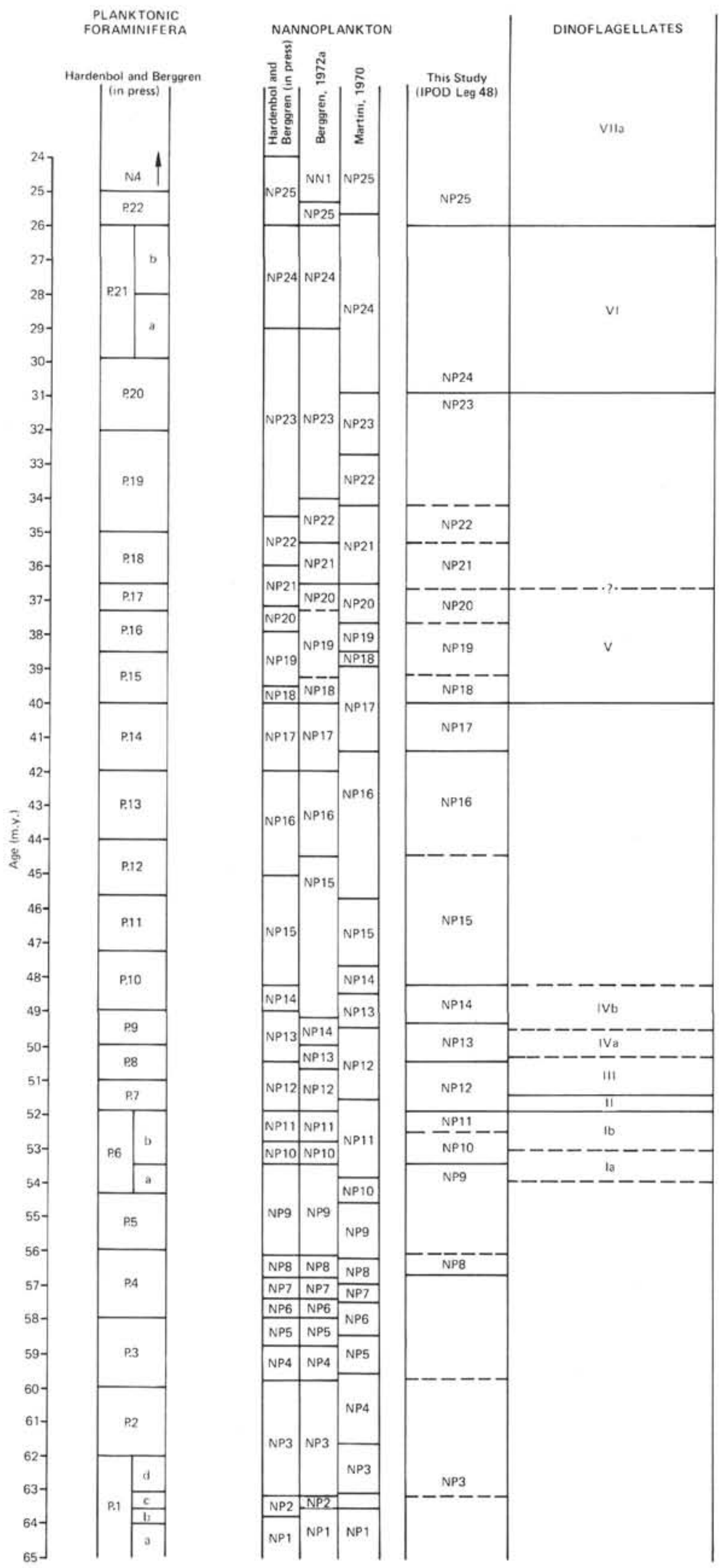

Figure 8. Comparison of correlation between Paleogene planktonic foraminifers and nannoplankton zones proposed by different authors. Time normalization of the nannoplankton zones is provided through their correlation with foram zones, which are plotted according to the Hardenbol and Berggren (in press) time scale. 

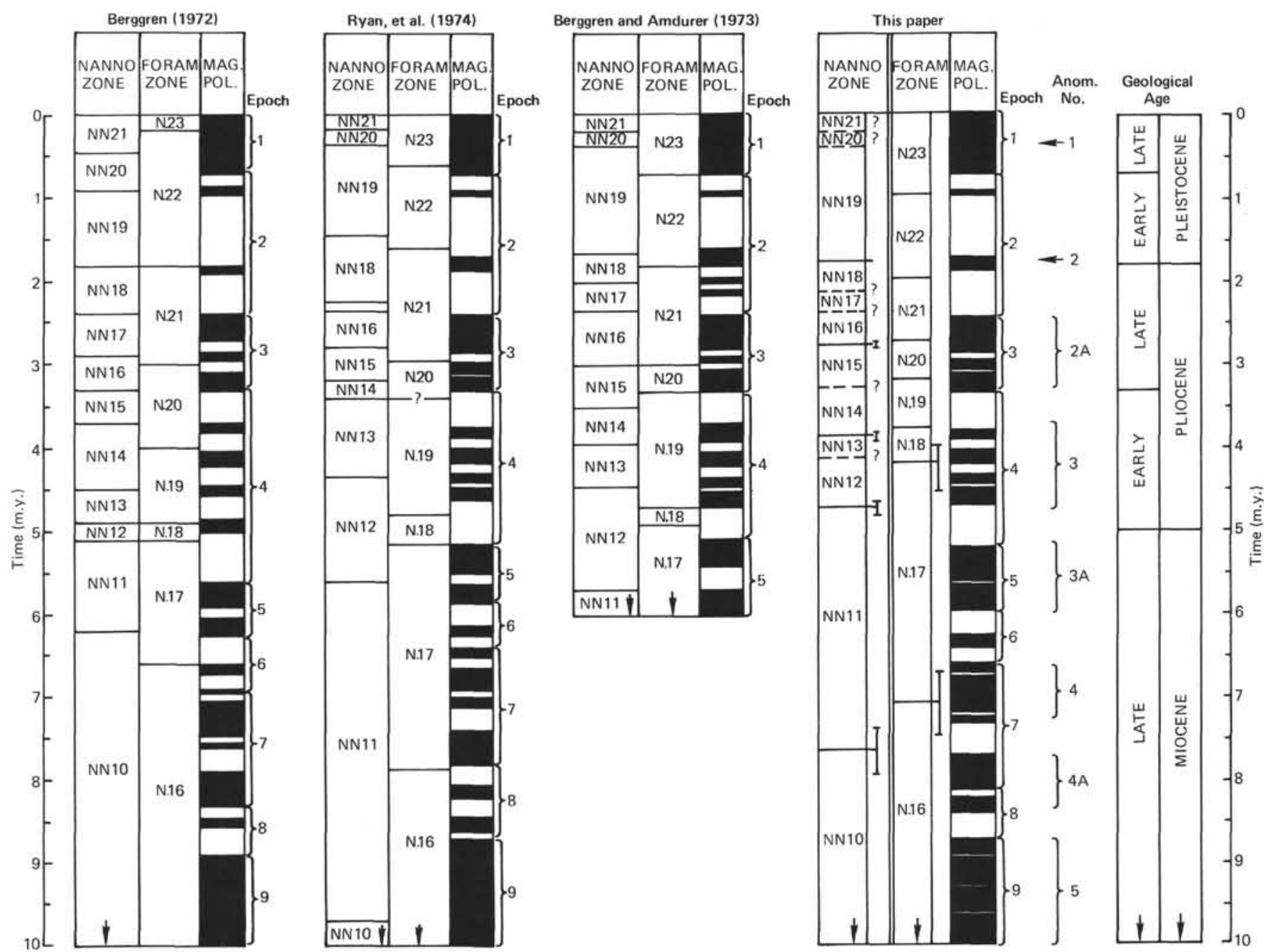

Figure 9. Comparison of late Neogene magnetobiostratigraphy scales of different authors. Simultaneous paleomagnetic and biostratigraphic studies allow the direct correlation of the Mediterranean (Ryan et al., 1974) and northeast Atlantic (this paper) biostratigraphies to the magnetic polarity time scale, so that biostratigraphic comparisons can be made between these two regions with reference to this "absolute" time scale.

ing and possibly significant differences between the late Cenozoic records in these two regions. These differences may be attributed to paleoceanographic and paleoclimatic causes.

Magnetobiostratigraphic studies of the early Paleogene sediments at Sites 403 to 405 , off the southwest margin of the Rockall Plateau, allow the recognition of a sequence of polarity reversals that can be correlated with anomalies 22 to 24. The biostratigraphic ages of these anomalies, deduced from this study, facilitate the recalibration of the Paleogene part of the Cenozoic polarity time scale. This revised polarity time scale is linked to the geological time scale of Hardenbol and Berggren (in press) in Figure 6. Comparisons between nannofossil and foraminiferal zone determinations from the Leg 48 sediments suggest the need for minor modifications to the low latitude zonal correlations of Hardenbol and Berggren (in press) when applied to the northeast Atlantic region. A summary of the proposed Cenozoic and Cretaceous magnetobiostratigraphic scale for the northeast Atlantic is presented in Figure 2.
This synthesis has demonstrated the usefulness of combined paleomagnetic and biostratigraphic studies, and it is to be expected that further studies of this type will lead to a rapid refinement of the correlation between the magnetic polarity and biostratigraphic time scales, and contribute significantly to the ultimate goal of providing an "absolute" calibration of the Cenozoic geological time scale.

\section{ACKNOWLEDGMENTS}

We are very grateful to Drs. W.A. Berggren and D. Curry for their helpful reviews of the manuscript, and also to Dave Roberts and Lucien Montadert for helpful discussion at various stages of the work.

\section{REFERENCES}

Benson, R.H., 1972. Preliminary report on the ostracods of holes 117 and 117A. In Laughton, A.S., Berggren, W.A., et al., Initial Reports of the Deep Sea Drilling Project, v. 12: Washington (U.S. Government Printing Office), p. 427-432. 
Breggren, W.A., 1972a. Cenozoic time-scale - some implications for regional geology and paleobiogeography, Lethaia, v. 5, p. 195-215.

, 1972b. Cenozoic biostratigraphy and paleobiogeography of the North Atlantic. In Laughton, A.S., Berggren, W.A., et al., Initial Reports of the Deep Sea Drilling Project, v. 12: Washington (U.S. Government Printing Office), p. 965-1001.

, 1972c. Late Pliocene-Pleistocene glaciation. In Laughton, A.S., Berggren, W.A., et al., Initial Reports of the Deep Sea Drilling Project, v. 12: Washington (U.S. Government Printing Office), p. 935-963.

Berggren, W.A. and Amdurer, M., 1973. Late Paleogene (Oligocene) and Neogene planktonic foraminiferal biostratigraphy of the Atlantic Ocean (Lat. $30^{\circ} \mathrm{N}$ to Lat. $30^{\circ} \mathrm{S}$ ), Riv. Ital. Paleont. Strat., v. 79, p. 337-392.

Berggren, W.A. and Hollister, C., 1974. Paleogeography, Paleobiogeography and the history of circulation of the Atlantic Ocean. In Hay, W.W. (Ed.), Studies in oceanography: Soc. Econ. Paleontol. Mineral., Spec. Publ., 20, p. 126-186.

Berggren, W.A., Phillips, J.D., Bertels, A., and Wall, D., 1967. Late Pliocene-Pleistocene stratigraphy in deep-sea cores from the south central North Atlantic, Nature, v. 216, p. 253-254.

Bizon, G. and Müller, C., 1977. Remarks on some biostratigraphic problems in the Mediterranean Neogene: Symposium "Histoire Structurale des Bassins Méditerranéens" -Split 1976-, p. $381-390$.

, 1978. Remarks on the determination of the Plio/Pleistocene boundary in the Mediterranean. In Hsü, K.J., Montadert, L., et al., Initial Reports of the Deep Sea Drilling Project, v. 42, Part 1: Washington (U.S. Government Printing Office), p. 847-854.

Bjorklund, K.R., 1976. Radiolaria from the Norwegian Sea, Leg 38 of the Deep Sea Drilling Project. In Talwani, M., Udintsev, G., et al., Initial Reports of the Deep Sea Drilling Project, v. 38, Washington (U.S. Government Printing Office), p. 1101-1168.

Blakely, R.J., 1974. Geomagnetic reversals and crustal spreading rates during the Miocene, J. Geophys. Res., v. 79, p. 2979-2985.

Blow, W.H., 1969. Late middle Eocene to Recent planktonic foraminiferal biostratigraphy. Proc. I. Intern. Conf. Planktonic Microfossils (Geneva, 1976), p. 199-421.

Bukry, D., 1972. Further comments on coccolith stratigraphy, Leg 12, Deep Sea Drilling Project. In Laughton, A.S., Berggren, W.A., et al., Initial Reports of the Deep Sea Drilling Project, v. 12: Washington (U.S. Government Printing Office), p. 1071-1083.

Bukry, D. and Bramlette, M.N., 1970. Coccolith age determinations Leg 3, Deep Sea Drilling Project. In Maxwell, A.E., von Herzen, R., et al., Initial Reports of the Deep Sea Drilling Project, v. 3, Washington (U.S. Government Printing Office), p. 589-611.

Cepek, P. and Hay, W.W., 1969. Calcareous nannoplankton and biostratigraphic subdivision of the Upper Cretaceous, Gulf Coast Assoc. Geol. Soc. Trans., v. 19, p. 323-336.

Chamalaun, F.H. and McDougall, I., 1966. Dating geomagnetic polarity epochs in Reunion, Nature, v. 210, p. 1212-1214.

Costa, L.C. and Downie, C., 1976. The distribution of the dinoflagellate Wetzeliella in the Palaeogene of north-western Europe, Palaeontology, v. 19, p. 591-614.

Costa, L. and Müller, C., in press. Correlation of Cenozoic dinoflagellate and nannoplankton zones from the NE Atlantic and NW Europe, News. Stratigr.

Cox, A., 1969. Geomagnetic reversals, Science, v. 163, p. 237-245.
Cox, A., Doell, R.R., and Dalrymple, G.B., 1963. Geomagnetic polarity epochs and Pleistocene geochronometry, Nature, v. 198 , p. 1049-1051.

, 1964. Reversals of the earth's magnetic field, Science, v. 144 , p. $1537-1543$.

1967. Reversals of the Earth's magnetic field, Scientific American, v. 216, p. 44-54.

Doell, R.R. and Dalrymple, G.B., 1966. Geomagnetic polarity epochs: A new polarity event and the age of the Brunhes-Matuyama boundary, Science, v. 152, p. 1060-1061.

Eaton, G.L., 1971. The use of microplankton in resolving stratigraphical problems in the Eocene of the Isle of Wight, $J$. Geol. Soc., v. 127 , p. 281-284.

Emilia, D.A. and Heinrichs, D.F., 1969. Ocean floor spreading: Olduvai and Gilsa events in the Matuyama epoch, Science, v. 166, p. 1267-1269.

Faller, A., 1975. Palaeomagnetism of the oldest Tertiary basalts in the Kangerdlugssuaq area of east Greenland, Bull. Geol. Soc Denmark, v. 24, p. 173-178.

Glass, B., Ericson, D.B., Heezen, B.C., Opdyke, N.D., and Glass, J.A., 1967. Geomagnetic reversals and Pleistocene chronology, Nature, v. 216, p. 437-440.

Green, K.A. and Brecher, A., 1974. Preliminary paleomagnetic results for sediments from site 263, Leg 27. In Heirtzler, J., Veevers, J., et al., Initial Reports of the Deep Sea Drilling Project, v. 27: Washington (U.S. Government Printing Office), p. 405-413.

Hailwood, E.A. Tarling, D.H., Mitchell, J.G., and Løvlie, R., 1973. Preliminary observations on the palaeomagnetism and radiometric ages of the Tertiary basalt sequence of Scoresby Sund, east Greenland, Rapp. Gronlands geol. Unders.,v. 58, p. $43-47$.

Haq, B.U., Premoli-Silva, J., and Lohmann, G.P., 1977. Calcareous plankton paleobiogeographic evidence for major climatic fluctuations in the early Cenozoic Atlantic Ocean, J. Geophys. Res., v. 82, p. 3861-3876.

Hardenbol, J. and Berggren, W.A., in press. A new Paleogene numerical time scale, Am. Assoc. Petrol. Geol. Bull.

Harland, W.B., Smith, A.G., and Wilcock, B., 1964. The Phanerozoic time-scale, Geol. Soc. London Quart. J., v. 120S, p. 1-458.

Hays, J.D., Saito, T., Opdyke, N.D., and Burckle, L.M., 1969. Pliocene-Pleistocene sediments of the equatorial Pacific: their paleomagnetic, biostratigraphic and climatic record, Geol. Soc. Am. Bull., v. 80, p. 1481-1513.

Heirtzler, J.R., Dickson, G.O., Herron, E.M., Pitman, W.C., III, and Le Pichon, X., 1968. Marine magnetic anomalies, geomagnetic field reversals, and motions of the ocean floor and continents, J. Geophys. Res., v. 73, p. 2119-2136.

Jarrard, R.D., 1974. Palaeomagnetism of some Leg 27 sediment cores. In Heirtzler, J., Veevers, J.J., et al., Initial Reports of the Deep Sea Drilling Project, v. 27: Washington (U.S. Government Printing Office), p. 415-423.

Larson, R.L. and Hilde, T.W.C., 1975. A revised time scale of magnetic reversals for the early Cretaceous and late Jurassic, $J$. Geophys. Res., v. 80, p. 2586-2594.

McDougall, I., and Tarling, D.H., 1963. Dating geomagnetic polarity zones, Nature, v. 202, p. 171-172.

Manivit, H., 1971. Nannofossiles calcaires du Crétacé français (Aptien-Maestrichtien). Essai de biozonation appuyée sur les stratotypes: Thesis Facul. Sci. Orsay.

Manum, S.B., 1976. Dinocysts in Tertiary Norwegian-Greenland Sea sediments (Deep Sea Drilling Project Leg 38), with observations on palynomorphs and palynodebris in relation to environment. In Talwani, M., Udintsev, G., et al., Initial 
Reports of the Deep Sea Drilling Project, v. 38, Washington (U.S. Government Printing Office), p. 897-919.

Martini, E., 1971. Standard Tertiary and Quaternary calcareous nannoplankton zonation, Proc. Second Planktonic Conf., Roma, 1970 , v. 2, p. 739-785.

Martini, E. and Müller, C., 1976. Eocene to Pleistocene silicoflagellates from the Norwegian-Greenland Sea (DSDP Leg 38). In Talwani, M., Udintsev, G., et al., Initial Reports of the Deep Sea Drilling Project, v. 38: Washington (U.S. Government Printing Office), p. 857-895.

Müller, C., 1976. Tertiary and Quaternary calcareous nannoplankton in the Norwegian-Greenland Sea, DSDP Leg 38. In Talwani, M., Udintsev, G., et al., Initial Reports of the Deep Sea Drilling Project, v. 38: Washington (U.S. Government Printing Office), p. 823-841. 1978. Calcareous nannofossils from the Mediterranean, Leg 42A of the Deep Sea Drilling Project. In Hsü, K.J., Montadert, L., et al., Initial Reports of the Deep Sea Drilling Project, v. 42, Part 1: Washington (U.S. Government Printing Office), p. 727-754.

Opdyke, N.D., 1972. Paleomagnetism of deep sea cores, Rev. Geophys. Space Phys., v. 10, p. 213-249.

Pechersky, D.M. and Khramov, A.N., 1973. Mesozoic palaeomagnetic scale of the USSR, Nature, v. 244, p. 499-501.

Perch-Nielsen, K., 1972. Remarks on the late Cretaceous to Pleistocene coccoliths from the North Atlantic. In Laughton, A.S., Berggren, W.A., et al., Initial Reports of the Deep Sea Drilling Project, v. 12: Washington (U.S. Government Printing Office), p. 1003-1069.

Phillips, J.D., Berggren, W.A., Bertels, A., and Wall, D., 1968. Palaeomagnetic stratigraphy and micropalaeontology of three deep-sea cores from the central north Atlantic Ocean, Earth Planet. Sci. Lett., v. 4, p. 118-130.

Poore, R.Z. and Berggren, W.A., 1974. Pliocene biostratigraphy of the Labrador Sea, Calcareous Plankton J. Foram Res., v. 4 , p. 91-108.

Premoli Silva, I., Napoleone, G., and Fischer, A.G., 1974. Risultati Preliminari sulla stratigrafia paleomagnetica della scaglia Cretaceo-Paleocenica della sezione di Gubbio (Appennine centrale), Soc. Geol. Italiana Boll., v. 93, p. 647-659.
Ryan, W.B.F., Cita, M.B., Dreyfus Rawson, M., Burckle, L.H., and Saito, T., 1974. A paleomagnetic assignment of Neogene stage boundaries and the development of isochronous datum planes between the Mediterranean, the Pacific and Indian oceans, in order to investigate the response of the world ocean to the Mediterranean "salinity crisis," Riv. Ital. Paleont., v. 80 , p. 631-688.

Schrader, H.J. and Fenner, J., 1976. Norwegian Sea Cenozoic diatom biostratigraphy and taxonomy. In Talwani, M., Udintsev, G., et al., Initial Reports of the Deep Sea Drilling Project, v. 38, Washington (U.S. Government Printing Office), p. 921-1099.

Sclater, J.G., Jarrard, R.D., McGowran, B., and Gartner, S., Jr., 1974. Comparison of the magnetic and biostratigraphic time scales since the Late Cretaceous. In von der Borch, C.C., Sclater, J.G., et al., Initial Reports of the Deep Sea Drilling Project, v. 22: Washington (U.S. Government Printing Office), p. 381-386.

Sigal, J., 1977. Essai de zonation du Crétacé Méditerranéen à l'aide des foraminifères planctoniques, Géologie Mediterranéene, v. 4, p. 99-108.

Soper, N.J., Downie, C., Higgins, A.C., and Costa, L.I., 1976. Biostratigraphic ages of Tertiary basalts on the east Greenland continental margin, and their relationship to plate separation in the Northeast Atlantic, Earth Planet. Sci. Lett., v. 32, p. 149-157.

Talwani, M., Windisch, C.C., and Langseth, M.G., 1971. Reykjanes ridge crest: a detailed geophysical survey, $J$. Geophys. Res., v. 76, p. 473-517.

Tarling, D.H. and Mitchell, J.G., 1976. Revised Cenozoic polarity time scale, Geology, v. 4, p. 133-136.

Thierstein, H.R., 1971. Tentative Lower Cretaceous calcareous nannoplankton zonation, Eclog. Geol. Helv., v. 64, p. 459-488.

, 1973. Lower Cretaceous calcareous nannoplankton biostratigraphy, Abh. Geol. Bundesanst., Wien, v. 29, p. 1-52.

van Hinte, J.E., 1976. A Cretaceous time scale, Am. Assoc. Petrol. Geol. Bull., v. 60, p. 498-516.

Vine, F.J. and Matthews, D.H., 1963. Magnetic anomalies over oceanic ridges, Nature, v. 199, p. 947-949. 